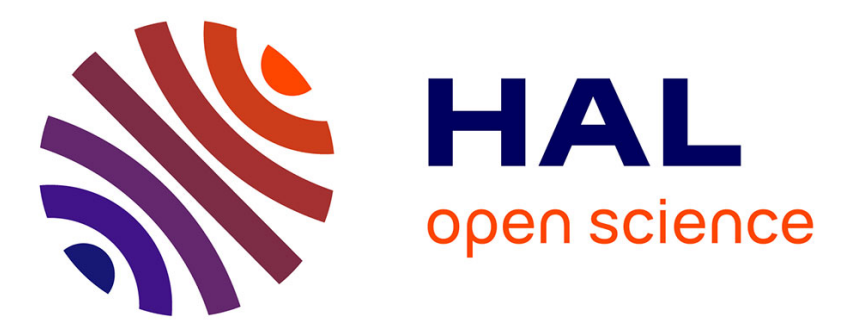

\title{
Supergene manganese ore records 75 Myr-long Campanian to Pleistocene geodynamic evolution and weathering history of the Central African Great Lakes Region - Tectonics drives, climate assists
}

Thierry de Putter, Gilles Ruffet

\section{To cite this version:}

Thierry de Putter, Gilles Ruffet. Supergene manganese ore records 75 Myr-long Campanian to Pleistocene geodynamic evolution and weathering history of the Central African Great Lakes Region Tectonics drives, climate assists. Gondwana Research, 2020, 83, pp.96-117. 10.1016/j.gr.2020.01.021 . insu-02504724

\section{HAL Id: insu-02504724 \\ https://hal-insu.archives-ouvertes.fr/insu-02504724}

Submitted on 11 Mar 2020

HAL is a multi-disciplinary open access archive for the deposit and dissemination of scientific research documents, whether they are published or not. The documents may come from teaching and research institutions in France or abroad, or from public or private research centers.
L'archive ouverte pluridisciplinaire HAL, est destinée au dépôt et à la diffusion de documents scientifiques de niveau recherche, publiés ou non, émanant des établissements d'enseignement et de recherche français ou étrangers, des laboratoires publics ou privés. 


\section{Journal Pre-proof}

Supergene manganese ore records $75 \mathrm{Myr}-$ long Campanian to Pleistocene geodynamic evolution and weathering history of the Central African Great Lakes Region - Tectonics drives, climate assists

Thierry De Putter, Gilles Ruffet

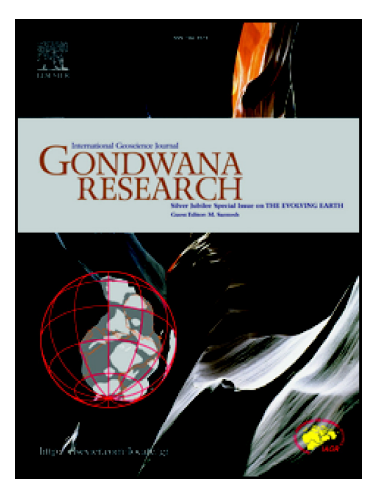

PII:

S1342-937X(20)30079-4

DOI: https://doi.org/10.1016/j.gr.2020.01.021

Reference:

GR 2307

To appear in:

Gondwana Research

Received date:

14 May 2019

Revised date:

24 January 2020

Accepted date:

31 January 2020

Please cite this article as: T. De Putter and G. Ruffet, Supergene manganese ore records $75 \mathrm{Myr}$-long Campanian to Pleistocene geodynamic evolution and weathering history of the Central African Great Lakes Region - Tectonics drives, climate assists, Gondwana Research(2020), https://doi.org/10.1016/j.gr.2020.01.021

This is a PDF file of an article that has undergone enhancements after acceptance, such as the addition of a cover page and metadata, and formatting for readability, but it is not yet the definitive version of record. This version will undergo additional copyediting, typesetting and review before it is published in its final form, but we are providing this version to give early visibility of the article. Please note that, during the production process, errors may be discovered which could affect the content, and all legal disclaimers that apply to the journal pertain.

(C) 2020 Published by Elsevier. 
Supergene manganese ore records 75 Myr-long Campanian to Pleistocene geodynamic evolution and weathering history of the Central African Great Lakes Region - tectonics drives, climate assists

\author{
Thierry De Putter ${ }^{\mathrm{a}}$, Gilles Ruffet ${ }^{\mathrm{b}, \mathrm{c}}$ \\ ${ }^{a}$ Royal Museum for Central Africa, Geodynamics and Mineral Resources, 13 Leuvensesteenweg, B- \\ 3080 Tervuren, Belgium \\ ${ }^{\mathrm{b}}$ CNRS (CNRS/INSU) UMR 6118, Géosciences Rennes, F-35042 Rennes Cedex, France \\ ${ }^{\mathrm{c}}$ Université de Rennes 1, Géosciences Rennes, F-35042 Rennes Cedex, France
}

\begin{abstract}
The southeastern part of the Democratic Republic of the Congo locally hosts Proterozoic manganese deposits. The deposits of Kisenge-Kamata are the most significant, but manganese ores are also known to occur at Kasekelesa (former Katanga Province) and Mwene-Ditu (former Kasai Province). For the present study, cryptomelane-rich samples from these two localities were dated, using the ${ }^{40} \mathrm{Ar} /{ }^{39} \mathrm{Ar}$ step-heating method with a $\mathrm{CO}_{2}$ laser probe. The ages obtained are within a range of c. $77 \mathrm{Myr}$ to c. $2 \mathrm{Myr}$. Cryptomelane formation took place at c. $76.4 \mathrm{Ma}$, c. $59.6 \mathrm{Ma}$, c. $45 \mathrm{Ma}$, c. $35 \mathrm{Ma}$, c. $23.8 \mathrm{Ma}$, c. $15.4 \mathrm{Ma}$, and c. $13.3 \mathrm{Ma}$ at Kasekelesa, and it occurred at c. $35 \mathrm{Ma}$, c. $22.4 \mathrm{Ma}$, c. $15 \mathrm{Ma}$, c. 5.57.2 Ma, c. 3.6 Ma, and c. 2.1-2.3 Ma at Mwene-Ditu. The Campanian age (c. 76.4 Ma) recorded at Kasekelesa is the oldest ${ }^{40} \mathrm{Ar} /{ }^{39} \mathrm{Ar}$ age that has up to now been recorded for $\mathrm{Mn}$ ores from Africa. It documents the formation of oxidized ore along a Campanian or older erosion surface, which could be part of the 'African Erosion Surface'. The complete age record suggests that continent-wide tectonics accounts for most of the recognized supergene ore formation episodes, controlled by vertical lithospheric movements that are ultimately
\end{abstract}


responsible for alternating stages of landscape stability and erosion. Tectonics is thus regarded as the first-order control for secondary ore formation in Central Africa, over the last 80 Myr. Climate is a second-order control, because sufficient water supply is needed for supergene enrichment, whereby climatic conditions are recognized to have been favourable during some relatively cold Late Mesozoic and Paleogene periods, as well as during some humid and warm Neogene stages.

Keywords : ${ }^{40} \mathrm{Ar} /{ }^{39} \mathrm{Ar}$, African Erosion Surface, continental denudation, Democratic Republic of the Congo, Kasekelesa, Katanga, Mwene-Ditu, manganese

\section{Introduction}

The African continent hosts several large manganese deposits, many of them capped with a supergene cover (e.g. Beukes et al., 2016). Primary ores are mostly of Paleoproterozoic age, whereas the supergene cover formed much more recently, predominantly during the Cenozoic. Available ${ }^{40} \mathrm{Ar} /{ }^{39} \mathrm{Ar}$ ages for supergene manganese ores vary strongly between different parts of Africa, with Paleocene to Pliocene ores in West Africa (Hénocque et al., 1998; Colin et al., 2005; Beauvais et al., 2008) and younger, Eocene to Pliocene, ores in southern Africa (Gutzmer et al., 2012). Recent investigation on the 'Thrust Manganese' ore in the Kalahari Manganese Fields, which is located at the contact with the Kalahari unconformity, documents the precipitation of supergene apatite formed in the ore at 77士7.5 Ma (Vafeas et al., 2018a \& b).

In Central Africa, the major Paleoproterozoic Kisenge deposit, in the western part of the Lualaba Province (formerly Katanga) of the Democratic Republic of the Congo (DRC), has yielded Mio-Pliocene ages for the supergene ores (Decrée et al., 2010; De Putter et al., 2015). Some other deposits occur in other parts of the former Katanga Province, as well as in the 
former Kasai Province. The geochronological study of their associated supergene ores is the subject of the present study. It considerably broaden the range of ages first obtained for the Kisenge Mn ore. They allow constraining the local geodynamics which is marked, from the Oligocene onwards, by the opening of the western branch of the East African Rift System (EARS) (Pik et al., 2008; Roberts et al., 2012; De Putter et al., 2015). At a continental scale, ages of supergene ores provide relevant constraints to understand the dynamics of cratonic denudation, in a continent where cratonic terranes cover huge areas (Beauvais \& Chardon, 2013). As such process relates to $1^{\text {st }}$ order factors, the correlation of ages of supergene ores at continental scale may therefore open a window on the dynamics of Africa under tectonic and/or climatic forcing (a.o. Sahagian, 1988; Burke \& Gunnell, 2008; Begg et al., 2009; Beauvais \& Chardon, 2013; Venancio da Silva et al., 2019). It is the purpose of the present study to bring additional age constraints on the manganese deposits of Mwene-Ditu and Kasekelesa.

\section{Geological and geodynamic context}

The substrate of the western part of the former Katanga Province and the southern part of the neighbouring former Kasai province, south-eastern DRC, consists of a poorly documented granitic-gneissic basement known as the Kasai Block, of Archean and Paleoproterozoic age (Cahen \& Lepersonne, 1967; Lepersonne, 1974; Boven et al., 2011). Paleoproterozoic sediments, which unconformably overlie this granito-gneissic basement, locally include manganese deposits, most notably as primary carbonate ore lenses within grey graphitic shale as observed at Kisenge-Kamata (De Putter et al., 2018).

Like the Kisenge-Kamata ores, the Mwene-Ditu deposits (Mont Mwatshimwa, Kasai region)

(Fig. 1) are part of the sequence of Paleoproterozoic metasediments that overlie the Kasai Block. The spessartine-rich primary manganese ore is associated with grey graphitic shales, 
occurring in a region where Paleoproterozoic banded iron formations are also known to occur (Morelli \& Raucq, 1961, 1962).

The Kasekelesa manganese deposit (Katanga region) (Fig. 1) is considered to be a vein-type deposit $\left(\mathrm{N} 10-20^{\circ} \mathrm{W}\right.$ to $\left.\mathrm{N} 30^{\circ} \mathrm{E}\right)$, located close to the present-day contact between the Kasai Block and the overlying Neoproterozoic Roan Group (Moureau, 1948; Schuiling, 1955) (Fig. 1). The Kasekelesa deposit could be comparable with deposits at Kampumba and Mansa in northern Zambia, close to the contact between the Bangweulu Block and the Neoproterozoic Roan Group cover (see Green \& Daly, 1982).

After the late phases of the Lufilian orogenic event, which culminated at c. $530 \mathrm{Ma}$ (Cailteux \& De Putter, 2019), the Katanga area underwent progressive denudation. The pre-300 Ma surface of the northern part of Katanga was low-lying with isolated inselbergs piercing the Permian (Karroo) sedimentary cover (Dumont, 1991).

The Phanerozoic sedimentary cover of the Kasai Block has been recently investigated through an extensive drilling program in the study area and the neighbouring North-eastern Angola by De Beers Exploration (Roberts et al., 2015). In the study area, coarse-grained conglomerates of alluvial fan origin (C3) rest on a highly uneven basement topography. The conglomerates are conformably overlain by a sequence of sandstones, laminated shales and siltstones of mixed fluvial channel, eolian dune and ephemeral lake origin (C4). Unit C4 is the thickest and most widespread sedimentary unit in the Kasai Region. A pilot detrital zircon sample collected at the base of $\mathrm{C} 3$ yields a $~ 79$ Ma population of detrital grains, possibly relating to the emplacement of the Angolan Albian-Aptian kimberlites. These results suggest a Late Cretaceous age (or younger) for units C3 and C4 (Roberts et al., 2015). Unexpected local variability and stratigraphic complexity are observed in the cover sequences from the Kasai region, which suggest a more tectonically active Mesozoic-Cenozoic basin history than 
has previously been assumed, with tectonic movements on major fault systems apparently playing a large role in the local stratigraphy (Roberts et al., 2015).

\section{${ }^{40} \mathrm{Ar} /{ }^{39} \mathrm{Ar}$ method}

Two batches of Mn oxide samples from Kasekelesa (RGM series) and Mwene-Ditu, Kasai (RG series), were analyzed by the ${ }^{40} \mathrm{Ar} /{ }^{39} \mathrm{Ar}$ method in step-heating using a $\mathrm{CO}_{2}$ laser probe coupled with a MAP 215 mass spectrometer. The procedure was described by Ruffet et al. (1991, 1995, 1997).

Irradiation of samples was performed at Mac Master Nuclear Reactor (Hamilton, Ontario, Canada) in the 8C facility. It lasted $50.967 \mathrm{~h}$ with a global efficiency $(\mathrm{J} / \mathrm{h})$ of $4.540 \times 10^{-5} \mathrm{~h}^{-1}$. The irradiation standard was sanidine TCRs $(28.608 \pm 0.033$ Ma according to Renne et al., 1998, 2010 and 2011)

Blanks were performed routinely each first or third/fourth run, and are subtracted from the subsequent sample gas fractions. Apparent age errors are plotted at the $1 \sigma$ level and do not include the errors on the ${ }^{40} \mathrm{Ar}^{*} /{ }^{39} \mathrm{Ar}_{\mathrm{K}}$ ratio and age of the monitor and decay constant. Plateau ages were calculated if $70 \%$ or more of the ${ }^{39} \mathrm{Ar}_{\mathrm{K}}$ was released in at least three or more contiguous steps which define apparent ages agreeing, to within $1 \sigma$, with the integrated age of the plateau segment. Pseudo-plateau ages can be defined on the basis of these same statistical validation criteria but for segments containing less than $70 \%$ of the ${ }^{39} \mathrm{Ar}_{\mathrm{K}}$ released. Indeed, Fleck et al. (1977) wrote: "The criteria for determining the presence or extent of an age plateau, however, remain somewhat subjective", pointing out that the amount of ${ }^{39} \mathrm{Ar}_{\mathrm{K}}$ released is not a disqualifying criterion. The errors on the ${ }^{40} \mathrm{Ar}^{*} /{ }^{39} \mathrm{Ar}_{\mathrm{K}}$ ratio and age of the monitor and decay constant are included in the final calculation of the error margins on the (pseudo-)plateau ages. 
Analytical data and parameters used for calculations (e.g. isotopic ratios measured on pure K, $\mathrm{Ca}$ and $\mathrm{Cl}$ salts; mass discrimination; atmospheric argon ratios; J parameter; decay constants) and reference sources are available in the supplementary data repository.

\section{${ }^{40} \mathrm{Ar} /{ }^{39} \mathrm{Ar}$ data processing}

All analyzes were duplicated and sample RGM 7041 was analyzed three times due to the complexity of the observed results. This complexity of ${ }^{40} \mathrm{Ar} /{ }^{39} \mathrm{Ar}$ results is rather common, both because of the complex nature of $\mathrm{Mn}$ oxides and the often long and frequently polyphase history they record (e.g. Vasconcelos et al., 1992, 1994; Ruffet et al., 1996; Beauvais et al., 2008).

As recalled in detail by De Putter et al. (2015), even though cryptomelane $\left(\mathrm{K}\left(\mathrm{Mn}^{4+}{ }_{7} \mathrm{Mn}^{3+}\right) \mathrm{O}_{16}\right)$, which is the K-rich $(>5 \%)$ end-member of a group of Mn oxides with tunnel structure (coronadite group, hollandite supergroup according to Biagioni et al., 2013), is the best candidate for ${ }^{40} \mathrm{Ar} /{ }^{39} \mathrm{Ar}$ dating, the reality imposed by sampling, the extent of the possible combinations between the various end-members of the coronadite group $(\mathrm{K}, \mathrm{Na}, \mathrm{Pb}$, $\mathrm{Ba}, \mathrm{Sr}$, etc. in tunnel structure) during the development of supergene systems and the possible presence of other frequently observed $\mathrm{Mn}$ oxides such as pyrolusite $\left(\mathrm{MnO}_{2}\right)$ or lithiophorite $\left((\mathrm{Al}, \mathrm{Li})\left(\mathrm{Mn}^{4+}, \mathrm{Mn}^{3+}\right)_{2} \mathrm{O}_{2}(\mathrm{OH})_{2}\right)$ leads most often to the analysis of composite materials which cannot be formally designated as cryptomelane. For this reason, the terminology "K-rich Mn oxide" will be used hereafter even if the material analyzed is mostly composed of cryptomelane, as confirmed by XRD analysis.

This material is just as suitable for $\mathrm{K}-\mathrm{Ar}$ (and ${ }^{40} \mathrm{Ar} /{ }^{39} \mathrm{Ar}$ ) geochronological investigations as pure cryptomelane because the existing structural $\mathrm{K}$ is contained in tunnel structures which ensures retentiveness of argon (Vasconcelos et al., 1992, 1994, 1995; Lippolt and Hautmann, 1995). 
Due to the complexity of obtained results, their processing must go beyond a simple visual examination of an age spectrum as often done for most geochronological studies. De Putter et al. (2015) presented some visualization and processing tools, three of them quite classical: the inverse isochron diagram (correlation diagram) $\left({ }^{36} \mathrm{Ar} /{ }^{40} \mathrm{Ar}\right.$ vs. ${ }^{39} \mathrm{ArK} /{ }^{40} \mathrm{Ar} *$; Turner, 1971 ; Roddick et al., 1980; Hanes et al., 1985) with least-squares fitting of the best straight line according to York (1969) and York et al. (2005); the probability density diagrams first used for ${ }^{39} \mathrm{Ar}_{-}{ }^{40} \mathrm{Ar}$ by Deino \& Potts (1992) and Vasconcelos et al. (1992); and the pseudo-plateau age (PPA) concept (Cheilletz et al., 1999). The others are more atypical and were developed for the analysis of multiphase systems. These tools, the degassing spectrum and the weighted age spectrum, are designed to visualize the degassing kinetics of argon during the stepheating procedure.

Inverse isochron diagram (correlation diagram), generally used to detect excess argon,allows analyzing the mixture between a so-called atmospheric component (atmospheric argon with possible excess argon) and a radiogenic component (with possible inherited argon), both constitutive of the argon present in the sample. It is a very powerful tool to probe analyzes frequently characterized by huge rates of atmospheric "contamination" and to identify radiogenic components poorly and imperfectly defined through conventional age spectrum calculations (presupposition of atmospheric ratios). Furthermore, due to the growth conditions of supergene minerals such as Mn oxides, the atmospheric component can only consist of atmospheric $\operatorname{argon}\left(\left({ }^{40} \mathrm{Ar} /{ }^{36} \mathrm{Ar}\right)_{\mathrm{i}}=298.56 \pm 0.104 \%\right.$ according to Lee et al. $\left.(2006)\right)$ and, as opportunely reminded by Vasconcelos (1999), non-compliance becomes a factor of invalidation as MSWD cut-off thresholds.

Taking argon degassing kinetics into consideration in the elaboration of age spectra is also an important factor for their appropriate deciphering. This argon degassing kinetics can be visualized in a degassing spectrum which reports for each step, versus $\%^{39} \mathrm{Ar}_{\mathrm{K}}$, the amount of 
${ }^{\mathrm{A}} \mathrm{Ar}$ (with $\mathrm{A}=36$ to 40 ) weighted by the temperature difference with the previous step $\left(\Delta \mathrm{T}^{\circ}\right)$, this ratio being normalized between 0 and 1 . This is expressed by the following formula: $\left({ }^{\mathrm{A}} \mathrm{Ar} / \Delta \mathrm{T}^{\circ}\right) /\left({ }^{\mathrm{A}} \mathrm{Ar} / \Delta \mathrm{T}^{\circ}\right)$ Max versus $\%{ }^{39} \mathrm{Ar}_{\mathrm{K}}$ (with $\left.{ }^{\mathrm{A}} \mathrm{Ar}={ }^{40} \mathrm{Ar}^{*},{ }^{39} \mathrm{Ar}_{\mathrm{K}},{ }^{37} \mathrm{Ar}_{\mathrm{Ca}},{ }^{36} \mathrm{Ar} \mathrm{Atm}\right) . \quad \mathrm{A}$ degassing spectrum provides, through the variations in the degassing rate it allows visualizing, information on the isotopic/radiogenic components likely to be present in the analyzed material and on their transition or overlapping domains.

A conventional age spectrum, which reports for each step the apparent ages vs $\%{ }^{39} \mathrm{Ar}_{\mathrm{K}}$, is a raw representation of the experiment that does not reflect the variations in the degassing rate during the successive temperature increments. In such a graphical representation, different steps corresponding to the same amount $\mathrm{Q}$ of ${ }^{39} \mathrm{Ar}_{\mathrm{K}}$ released will have the same width, regardless of the temperature increments $\left(\Delta \mathrm{T}^{\circ}\right)$ that produced them.. The weighting of ${ }^{39} \mathrm{Ar}_{\mathrm{K}}$ degassing by the temperature increments expressed by the formula $\%\left(\left({ }^{39} \mathrm{Ar}_{\mathrm{K}} / \Delta \mathrm{T}^{\circ}\right)\right.$ / $\left.\left({ }^{39} \mathrm{Ar}_{\mathrm{K}} / \Delta \mathrm{T}^{\circ}\right)_{\text {Max }}\right)$ allows to develop a weighted age spectrum that integrates the degassing rate. The weighted age spectrum results of the composition of the degassing spectrum and the conventional age spectrum. The width of a step accounting for an amount $\mathrm{Q}$ of argon released during a temperature increment $\Delta \mathrm{T}^{\circ}$ will be the same as that of a step accounting for an amount $\mathrm{x} . \mathrm{Q}$ of argon released during a temperature increment $\mathrm{x} . \Delta \mathrm{T}^{\circ}$. A weighted age spectrum allows weakly expressed but clearly identified radiogenic components (associated with degassing peaks) to be represented in proportion to their degassing rates.

However, since temperature $\left(\mathrm{T}^{\circ}\right)$ measurement during $\mathrm{CO}_{2}$ laser probe analysis is a major difficulty, the laser power control voltage $\left(\mathrm{V}_{\mathrm{T}^{\circ}}\right)$, a proxy indicator, was substituted. Therefore, the degassing spectrum $\left(\left({ }^{\mathrm{A}} \mathrm{Ar} / \Delta \mathrm{V}_{\mathrm{T}^{\circ}}\right) /\left({ }^{\mathrm{A}} \mathrm{Ar} / \Delta \mathrm{V}_{\mathrm{T}^{\circ}}\right)_{\text {Max }}\right.$ versus $\%{ }^{39} \mathrm{Ar}_{\mathrm{K}}$ (with $\mathrm{A}=36$ to 40$\left.)\right)$ and the weighted age spectrum (Apparent Ages versus \%(( $\left.\left.{ }^{39} \mathrm{Ar}_{\mathrm{K}} / \Delta \mathrm{V}_{\mathrm{T}^{\circ}}\right) /\left({ }^{39} \mathrm{Ar}_{\mathrm{K}} / \Delta \mathrm{V}_{\mathrm{T}^{\circ}}\right)_{\mathrm{Max}}\right)$, should only be used to visualize the degassing rate. 
Another process was implemented in this study. Resizing age spectra equates their statistical representativeness in probability density diagrams. (e.g. Fig. 2, 3 or 4). There are rarely two similar experiments in their development (number of steps, $\%$ of ${ }^{39} \mathrm{Ar}_{\mathrm{K}}$ degassing per step, etc.) because the degassing control is never perfect. For analyzes to be statistically comparable, it may be worthwhile for each of them to have the same number of steps by resizing age spectra, each step representing the same amount of degassed ${ }^{39} \mathrm{Ar}_{\mathrm{K}}$. Indeed, in the elaboration of the probability density diagrams (frequency diagrams) of the apparent ages, all the steps contribute almost equally, even weighted by their respective errors, whatever their respective $\%$ of ${ }^{39} \mathrm{Ar}_{\mathrm{K}}$ degassing. Obviously, this resizing (slicing and/or recombination) of the steps (apparent ages) requires a reappraisal of their respective errors by respecting the principle of weighted averages.

Although this sensible practice was already advocated by Vasconcelos (1999) or more recently by Feng \& Vasconcelos (2001) or Carmo \& Vasconcelos (2004), it is important to emphasize the value of duplicating experiments insofar as the results obtained are frequently very complex. Although most often reproducibility is fairly correct, it is nevertheless less than that usually observed in more conventional geochronological studies (magmatism, volcanism, metamorphism). This dissimilarity of behavior with respect to subsequent disturbances could express differences in their recording processes. More than conventional disturbances of a preexisting component of a given age through e.g. partial crystallization or partial resetting, observed disparities between duplicates suggest that, at least in part, they may be associated with neo-crystallized components (growth of younger generations of Mn oxides) which, depending on the selected grains, would be present in variable quantities or possibly absent. In-sample analytical dissimilarities could express some inter-grain heterogeneities. It should be kept in mind that a step-heating experiment aims at separating the various argon components present in a sample but that the result being rarely perfect, both 
because of the degassing profile adopted and the state of interpenetration of these components, duplication is often a sensible approach.

It is important to prioritize the panel of tools presented above. Degassing spectrum and the weighted age spectrum are only a support to the interpretation and they exclusively allow data to be visualized in a different and more complete way. Their use precedes the age validation process. Conventional tools (age spectrum and inverse isochron diagram (correlation diagram)) are at the heart of the age validation process because they alone allow the statistical validation of significant ages through plateau or pseudo-plateau ages and inverse isochron ages. The probability density diagram, conventional or calculated after resizing the age spectra, has no other purpose in this study than to allow a synthetic presentation of the previously validated ages.

The identification of characteristic disturbances of Mn-oxide ${ }^{40} \mathrm{Ar} /{ }^{39} \mathrm{Ar}$ age spectra, and their interpretation by Vasconcelos et al. (1994); Vasconcelos (1999); Ruffet et al. (1996); Hénocque et al.(1998); Hautmann \& Lippolt (2000); Colin et al.(2005) or Beauvais et al. (2008), will support the processing of the results from this study.

\section{Results}

The results for Kasekelesa and Mwene-Ditu will be presented sequentially because their records are quite different. Validated ages for both sites are reported in probability density plots in Fig. 2 (to the left, Kasekelesa; to the right, Mwene-Ditu). In this study, sample RGM 7041 is undoubtedly emblematic of the difficulties encountered in the processing of the ${ }^{40} \mathrm{Ar} /{ }^{39} \mathrm{Ar}$ experiments (Fig. 3). Three grains were analyzed because of the complexity of the obtained age spectra and the importance of the expected results. The three age spectra are quite similar with a hump shape which is all the more pronounced than maximum apparent ages are old. This hump shape expresses a mixture between components having distinct ages 
(Wijbrans \& McDougall, 1986; Ruffet et al., 1996; Vasconcelos, 1999; Beauvais et al., 2008). The low, and at times high temperature ages are maximum estimates of the age of the youngest generation (Ruffet et al., 1996; Beauvais et al., 2008). In this case, it is an early Miocene component clearly evidenced in $\alpha$ experiment where it is associated with a sharp degassing peak (1) and characterized by an impressive pseudo-plateau (21.5 $\pm 0.6 \mathrm{Ma})$ in the resulting weighted age spectrum. Even if this early Miocene event is less well expressed by the age spectra of the two other experiments $(\beta$ and $\gamma)$, its signature within the inverse isochron diagrams is, in all three cases, irrefutable as it is correlated with a huge atmospheric component which confers it a strong representativeness in the graphs. It is worth noting the concordance of the low and high temperature apparent ages ( $c f$. frequency diagram) for experiment $\beta$, as expected under the assumption of mixing of components with distinct ages. If we assume a mixture of distinct age components to explain the hump-shaped age spectra, the apparent ages of the intermediate temperature steps would be minimum estimates of the age of the oldest component. These estimates vary among experiments, from c. 62.6 Ma up to $76.4 \pm 0.3 \mathrm{Ma}$ (pseudo-plateau age over $29.9 \%$ of ${ }^{39} \mathrm{Ar}_{\mathrm{K}}$ ), due to heterogeneities between grains and distinct proportions of their "old" and "young" components. The oldest age, at c. $76.5 \mathrm{Ma}$, would be the best estimate of the age of the "old" component of hump-shaped RGM 7041 age spectra. Its validity is reinforced by the calculation in correlation diagram which confirms the existence of a $76.8 \pm 0.6 \mathrm{Ma}$ old radiogenic component with an atmospheric signature $\left(\left({ }^{40} \mathrm{Ar} /{ }^{36} \mathrm{Ar}\right)_{\mathrm{i}}=281.3 \pm 23.1\right)$. It should be noted that the upper segment of the $\alpha$ age spectrum, constituted partly by the c. 76.5 Ma pseudo-plateau is associated with 2 degassing peaks (2) and (3). This observation suggests that the old component could be composite (double), and that only the oldest term (c. $76.5 \mathrm{Ma}$ ), associated with the degassing peak of higher temperature (3), is fully separated. Decipherment of the two other experiments, and particularly for analysis $\gamma$, reinforces and complements this interpretation. 
Most of their degassing also occurs in 2 peaks, but in experiment $\gamma$, separation between components was apparently more favorable to the one associated with the lower temperature peak (2). Effectively, the weighting of its age spectrum as well as its processing through inverse isochron calculation clearly indicates that this degassing peak (2) characterizes a Paleocene $(59.6 \pm 0.2 \mathrm{Ma})$ component(neo- or partial re- crystallization) recorded subsequently to the upper Cretaceous initial crystallization. So, three experiments carried out on the same sample are needed to correctly decrypt the recorded information: Campanian crystallization of a first generation of Mn oxides followed by two subsequent disturbances in the Paleocene (Selandian) and Early Miocene, probably associated with neocrystallization of Mn oxides. This complexity, both a difficulty and a wealth, is due to the age of the material analyzed, as sample heterogeneity increases with the accumulation of subsequent disturbances and growth of successive new generations of Mn oxides.

This complexity at the sample level reflects the complexity at the Kasekelesa site scale with huge disparities between samples and an abundant chronological record. At least three other events are detected between the previously identified Paleocene and early Miocene ones. Despite slightly older apparent ages at low and high temperatures steps probably related to ${ }^{39} \mathrm{Ar}_{\mathrm{K}}$ recoil (initially highlighted in the endogenous domain by e.g. Turner \& Cadogan (1974), Harrison (1983), Ruffet et al. (1991) or Foland et al.(1992) and subsequently in the supergene domain by Ruffet et al. (1996) or Vasconcelos (1999)) and to remnants of an older component (Albian? see below sample RGM 2230), sample RGM $2163 \alpha$ provides the only plateau age for the Kasekelesa site at $45.0 \pm 0.1 \mathrm{Ma}$ (c. $76.8 \%$ of ${ }^{39} \mathrm{Ar}_{\mathrm{K}}$ released) (Fig. 4). The duplicated experiment RGM $2163 \beta$ provides a staircase shaped age spectrum, different from age spectrum yielded by experiment $\alpha$ but nevertheless consistent with it. This rather classical age spectrum shape expresses a late Eocene (Priabonian) disturbance, with a pseudo-plateau age at $35.0 \pm 0.2 \mathrm{Ma}$, superimposed on the previously identified Lutetian 
phase. This late Eocene disturbance is characterized by a fairly large degassing peak preceding the Lutetian one. Inverse isochron diagram confirms the existence of this Priobanian component $\left(35.4 \pm 1.0 \mathrm{Ma}\right.$ and $\left.\left({ }^{40} \mathrm{Ar} /{ }^{36} \mathrm{Ar}\right)_{\mathrm{i}}=288.1 \pm 7.2\right)$. The inverse isochron processing also identifies a Late Oligocene disturbance at $24.1 \pm 2.7 \mathrm{Ma}\left(\left({ }^{40} \mathrm{Ar} /{ }^{36} \mathrm{Ar}\right)_{\mathrm{i}}=297.9\right.$ \pm 3.9 ) relating to a sharp and intense degassing in the very low temperature steps.

Another evidence of the Lutetian event is provided by experiment RGM 2230 $\gamma$ (Fig. 4), with a pseudo-plateau age at $44.9 \pm 0.4 \mathrm{Ma}$, also identified during the inverse isochron diagram analysis $\left(43.3 \pm 1.2 \mathrm{Ma}\right.$ and $\left.\left({ }^{40} \mathrm{Ar} /{ }^{36} \mathrm{Ar}\right)_{\mathrm{i}}=302.6 \pm 3.0\right)$, despite a particularly complex age spectrum characterized by ${ }^{39} \mathrm{Ar}_{\mathrm{K}}$ recoil in the low temperature steps and the remains of an older component (Albian?) in the high temperature steps (apparent age at $109.3 \pm 0.8 \mathrm{Ma}$ ). This high temperature component is partially superimposed on a late Oligocene perturbation identifiable in the medium to high temperature steps. An even more pronounced late Oligocene disturbance is expressed in the intermediate to high temperature steps of age spectrum provided by duplicated experiment RGM 22308, to such an extent that it prohibits precise identification of the Lutetian phase. It is worth noting that the Albian apparent age of the fusion step is associated with a specific increase of the degassing rate, an unusual fact that seems to confirm the existence of an old radiogenic component.

The high temperature steps of the RGM 2164 experiments ( $\alpha$ and $\beta$ ) (Fig. 5) could also provide tenuous evidence of the existence of this Lutetian phase, but they mainly highlight the importance of the late Oligocene imprint in the development of the Kasekelesa site. Indeed, a late Oligocene component, illustrated by a peak at c. $23.8 \mathrm{Ma}$ in the probability density diagram of these two experiments, is validated by their simultaneous inverse isochron processing which allows to identify an age component at $24.1 \pm 0.4 \mathrm{Ma}\left(\left({ }^{40} \mathrm{Ar} /{ }^{36} \mathrm{Ar}\right)_{\mathrm{i}}=295.4\right.$ $\pm 3.0)$. 
But the late Oligocene event is first and foremost defined by sample RGM $8317 \gamma($ Fig. 5) with a pseudo-plateau age at $24.2 \pm 0.1 \mathrm{Ma}$ in the low to intermediate temperature steps validated by inverse isochron processing $\left(23.8 \pm 0.2 \mathrm{Ma}\right.$ and $\left.\left({ }^{40} \mathrm{Ar} /{ }^{36} \mathrm{Ar}\right)_{\mathrm{i}}=301.0 \pm 1.0\right)$. The weighting of this age spectrum through the integration of its degassing profile also shows how important this Oligocene component is. On the other hand, the much older phase suggested by the intermediate to high temperature apparent ages (fusion step is as old as $114.5 \pm 0.6 \mathrm{Ma}$ ), cannot be specified. The duplicated experiment RGM $8317 \delta$ provides a fundamentally different staircase-shaped age spectrum within which the Oligocene component is merely a vestige (maximum apparent age in the high temperature steps at $23.7 \pm 0.2 \mathrm{Ma}$ ) partly overprinted by a subsequent Middle Miocene component(c. 13.5 Ma?).

As for the Lutetian event partially erased during the Oligocene, evidences of an Oligocene episode partially erased during subsequent middle and late Miocene events are provided by sample RGM 13029 (mainly experiment $\alpha$ ) and to a lesser extent also by sample RGM 12046 (Fig. 6). Indeed, the Miocene disturbance is much more sizeable within sample RGM 12046 for which degassing occurs in three clearly distinct peaks (labelled (1), (2) and (3)). The two peaks in the low to intermediate temperature domain indicate that the disturbance of the Oligocene component (peak (3) occurs in two stages, first during the Langhian (peak (2)) and then during the Serravallian (peak (1)), as suggested by the pseudo-plateau ages at c. 1515.5 $\mathrm{Ma}$ and 13-13.5 Ma, respectively. These pseudo-plateau ages are validated by the inverse isochron processing which allows detecting two distinct radiogenic components (both having an atmospheric signature), at c. 13-13.5 Ma and c. 15.5 Ma (Fig. 6). Albeit of lesser magnitude, this double middle Miocene disturbance can also be detected within experiment RGM $13029 \alpha$. Although peaks (1) and (2) are only partially separated, the weighting process clearly reveals a double break in the staircase shaped age spectrum which corresponds to the two previously identified events. On the other hand, only the Serravallian radiogenic 
component is identified during inverse isochron processing, at $13.6 \pm 0.4 \mathrm{Ma}\left(\left({ }^{40} \mathrm{Ar} /{ }^{36} \mathrm{Ar}\right)_{\mathrm{i}}=\right.$ $297.3 \pm 2.2)$. Inverse isochron processing also validates a late Miocene component $(9.0 \pm 2.7$ Ma and $\left.\left({ }^{40} \mathrm{Ar} /{ }^{36} \mathrm{Ar}\right)_{\mathrm{i}}=297.6 \pm 2.5\right)$, which corresponds to the 5 first steps of RGM $13029 \alpha$ age spectrum.. The resizing of the four age spectra and the use of a frequency histogram of apparent ages sizably highlight the Langhian event.

The frequency ideogram (probability density diagram) of apparent ages (Fig.2 - lower part) as well as the synthesis of all validated ages (Fig.2 - upper part) resulting from previous processing allow to visualize the succession of the eight events recorded between the late Cretaceous and the late Miocene for samples from the Kasekelesa site (Fig. 2, left panel). The ages reported on the frequency histogram point to the significant validated maxima but the events listed probably cover broader periods that are best identified through explicit references to the corresponding chronostratigraphic stages.

The seven samples from the Mwene-Ditu deposit record a very different story from that deciphered at Kasekelesa insofar as they predominantly provide middle to late Miocene and Plio-Pleistocene apparent ages. Only two samples, RG 55584 and 55585(Fig. 7), provide older ages with (low temperature steps excepted) rather reproducible staircase-shaped age spectra which compare to those yielded by sample RGM 2164 (Kasekelesa: Fig. 5, see above). These age spectra suggest a strong disturbance during the Aquitanian (21-23 Ma) of an older phase that could be Priabonian based on the high temperature apparent ages at c. 35 Ma yielded by sample RG 55584. As it was observed for the couple RGM 2164/8317 (Kasekelesa site: Fig. 5, see above), sample RG 55585 shows that the older component is all the less preserved as the subsequent imprint, Aquitanian in this case, is sizeable. The two PPAs at c. $22.5 \mathrm{Ma}$ (RG $55585 \gamma$ and $\delta$ ) are validated by the inverse isochron processing which detects an Aquitanian radiogenic component (c. 22.1-22.8 Ma) with an atmospheric signature. On the other hand, validation by the isochron calculation of the middle Miocene 
(Langhian) component (c. $15 \mathrm{Ma}$ ) detected in the very low temperature steps of experiment RG $55585 \delta$ is not satisfactory because of the high (94 - 96.5\%) atmospheric contamination and the low level of the radiogenic component observed in the first degassing increments.

The other samples from the Mwene-Ditu deposit provide apparent ages younger than c. $10.3 \mathrm{Ma}$ which is probably a reminiscence of an older phase, at least as old as Tortonian. This is suggested by hump-shaped RG 55557 $\alpha$ age spectrum(Fig. 8) which expresses mixing of components with distinct ages. In addition to this former (pre-)Tortonian component, sample RG 55557 $\alpha$ reveals, in the low temperature steps, a Pliocene component $(4.0 \pm$ $0.4 \mathrm{Ma})$ validated by isochron calculation process $\left(3.6 \pm 0.8 \mathrm{Ma}\right.$ with $\left({ }^{40} \mathrm{Ar} /{ }^{36} \mathrm{Ar}\right)_{\mathrm{i}}=300.5 \pm$ $3.3)$.

Three samples from the Mwene-Ditu deposit (RG 55557, RG 55587 and RG 55589) highlight a long "Messinian" event(Fig. 8). A first phase called Messinian 1 is early Messinian in age. It is characterized by:

- a PPA at $7.0 \pm 0.1 \mathrm{Ma}$ (c. $38.9 \%$ of ${ }^{39} \mathrm{Ar}_{\mathrm{K}}$ released) calculated on the high temperature steps of experiment RG $55557 \beta$ despite a sizeable atmospheric contamination (62-66\%) and a strong disturbance in the low to intermediate temperature steps, the nature of which cannot be specified because its signature in the correlation diagram is not good;

- a PPA at 7.2 $\pm 0.1 \mathrm{Ma}$ (c. $59.5 \%$ of ${ }^{39} \mathrm{Ar}_{\mathrm{K}}$ released) yielded by sample $\mathrm{RG} 55587 \delta$ in spite of an ${ }^{39} \mathrm{Ar}$ recoil related disturbance in the low temperature steps;

- the apparent age at 7.0 $\pm 0.1 \mathrm{Ma}$ of the staircase-shaped age spectrum fusion step provided by experiment RG $55589 \varepsilon$

The inverse isochron processing of experiments RG 55557 $\beta$ and RG $55587 \delta$ validates the existence of a radiogenic component at c.7.1 Ma (Messinian 1), strengthening previously identified PAPs. The peak at c. 7.2 Ma of the probability density diagram of apparent ages of 
these two experiments, reinforced by the resizing of their age spectra, highlights this component.

The duplicated experiment performed on sample RG 55589 allows deciphering staircaseshaped age spectrum yielded by experiment $\varepsilon$. The age spectrum of experiment RG $55589 \theta$ has a similar but less pronounced staircase-shape. Above all, it shows in the intermediate temperature domain a pseudo-plateau at $5.6 \pm 0.1 \mathrm{Ma}$ which characterizes a component, called Messinian 2, superimposed on an older one, which could be the previously identified Messinian 1. The existence of such a late Messinian radiogenic component is corroborated by the isochron calculation $\left(5.5 \pm 0.2 \mathrm{Ma}\right.$ with $\left.\left({ }^{40} \mathrm{Ar} /{ }^{36} \mathrm{Ar}\right)_{\mathrm{i}}=300.5 \pm 16.1\right)$. This hypothesis of mixing between distinct components is supported by the degassing analysis. Degassing spectrum shows a prominent "low" temperature peak, identified as Messinian 2 because specifically associated with the previously identified pseudo-plateau at c. 5.6 Ma, overlapping with a smaller peak in the higher temperature domain which could characterize remnants of the slightly older Messinian 1 component (c. 7.1 Ma). As before, the signature of this component in the frequency diagram of the apparent ages is magnified by the resizing of age spectra with a sharp frequency peak at c. 5.6 Ma. These results show that if a Messinian event were to be considered, then it would necessarily be composite and could have lasted at least 1.5 Ma.

The Pliocene component observed in experiment RG 55557 $\alpha$ (see above) is not an isolated occurrence. It constitutes (Fig. 9) the main component of sample RG 55578 in experiment $\gamma$ with a plateau age at $3.6 \pm 0.1 \mathrm{Ma}\left(\mathrm{c} .73 .0 \%\right.$ of ${ }^{39} \mathrm{Ar}_{\mathrm{K}}$ released) and a remnant component in sample RG 55562 as shown by high temperature steps (pseudo-plateau age at $3.8 \pm 0.1 \mathrm{Ma}$ ) of staircase-shaped experiment $\alpha$. In both cases, this Pliocene radiogenic component is

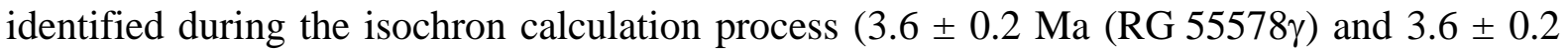
Ma (RG 55562 $\alpha)$ ) with an atmospheric signature. The staircase shape of experiment 
RG $55562 \alpha$ can be explained by the presence of a Pleistocene component $(2.1 \pm 0.1 \mathrm{Ma})$ clearly observed in the low temperature steps. This Pleistocene component is the main radiogenic component of the grain analyzed during duplicated experiment RG 55562 $\beta$, as suggested by the plateau age at $2.3 \pm 0.1 \mathrm{Ma}$ (c. $87.7 \%$ of ${ }^{39} \mathrm{Ar}_{\mathrm{K}}$ released). This also seems to be the case for the grain analyzed during duplicated experiment RG 55578 , with a pseudoplateau age at $2.1 \pm 0.1 \mathrm{Ma}$ in the intermediate to high temperature steps. As previously, this Pleistocene radiogenic component is validated through isochron calculations $(2.1 \pm 0.1 \mathrm{Ma}$ $(\mathrm{RG} 55562 \alpha) ; 2.1 \pm 0.1 \mathrm{Ma}(\mathrm{RG} 55562 \alpha) ; 2.2 \pm 1.4 \mathrm{Ma}(\mathrm{RG} 55578 \gamma)$ and $2.1 \pm 0.3 \mathrm{Ma}$ (RG 55578ס)) with in any case an atmospheric signature. Moreover, the frequency diagram of apparent ages makes it very prominent, especially after resizing the age spectra.

\section{Discussion}

\section{Background ${ }^{40} \mathrm{Ar} /{ }^{39} \mathrm{Ar}$ ages in the study area}

Supergene manganese oxide deposits that developed at the expense of the primary Mncarbonate ores at Kisenge-Kamata have previously been dated through ${ }^{40} \mathrm{Ar} /{ }^{39} \mathrm{Ar}$ analysis (De Putter et al., 2015). Based on those results, a sequence of uplift events has been inferred to have occurred during the Late Miocene (at 10.5 Ma; 3.6 Ma; 2.6 Ma), with evidence for some earlier Miocene events (at c. $\geq 19.2 \mathrm{Ma}, 15.7 \mathrm{Ma}, 14.2 \mathrm{Ma}$ and 13.6 Ma) (De Putter et al., 2015). Pre-Miocene events were not formally recorded for this deposit, although their existence was suggested by the oldest recorded ages. When that study was performed, comparisons with the rest of Africa were restricted to the 10.5-11 Ma period, correlatable with a roughly simultaneous event that has been recognized for the Kalahari Manganese Field, South Africa (Gutzmer et al., 2012). The rest of the record was regarded as strongly influenced by the opening of the EARS, from the Oligocene onward (De Putter et al., 2015). 


\section{Tectonics and meteoric fluids, driving forces of supergene ore formation}

Before examining in further detail the significance of the ages obtained in this work, it is worth reminding that chemical weathering is influenced by tectonic activity and subsequent fluid-rock interaction. The reasoning is that a landmass will only undergo weathering if it is exposed to the transit and action of meteoric fluids (e.g. rainwater): this exposition usually results from the vertical positive movements of the landmass, and the opposite movement of the water-table (Fig. 10). In other words, tectonic activity makes weathering possible while exposing/uplifting weathering-prone landmasses. Weathering will however proceed only if the exposed landmass receives sufficient meteoric fluids (rainwater) - which is a function of the climate (Maher and Chamberlain, 2014). Meteoric rainwater is in equilibrium with atmospheric $\mathrm{CO}_{2(\mathrm{~g})}$, which acidifies it (Liljestrand, 1985; Schmitt, 1999; De Putter et al., 2000), along:

(1) $\mathrm{CO}_{2(\mathrm{aq})}+\mathrm{H}_{2} \mathrm{O} \rightarrow \mathrm{H}^{+}+\mathrm{HCO}_{3}^{-}$

These acidic fluids percolate within the exposed landmass and react with Mn-bearing minerals in the unweathered ore - mostly rhodochrosite $\left(\mathrm{MnCO}_{3}\right)$ in this case (De Putter et $a l ., 2018)$ - in the presence of $\mathrm{O}_{2(\mathrm{~g})}$, along:

(2) $\mathrm{MnCO}_{3}+\mathrm{H}^{+} \rightarrow \mathrm{HCO}_{3}^{-}+\mathrm{Mn}^{2+}$

(3) $\mathrm{Mn}^{2+}+2 \mathrm{H}^{+}+2 \mathrm{O}_{2} \rightarrow \mathrm{Mn}^{3+}{ }_{2} \mathrm{O}_{3(\mathrm{~s})}+\mathrm{H}_{2} \mathrm{O}$

which combine partial acid neutralization (reaction 2) and a $\mathrm{Mn}^{2+} \rightarrow \mathrm{Mn}^{3+}$ oxidation (reaction 3) (Schmitt, 1999; Duckworth \& Martin, 2004). In the presence of $\mathrm{K}^{+}$and with an excess of $\mathrm{O}_{2}, \mathrm{Mn}^{3+}$ partially converts to $\mathrm{Mn}^{4+}$, and cryptomelane $\left(\mathrm{K}\left(\mathrm{Mn}^{4+}{ }_{7} \mathrm{Mn}^{3+}\right) \mathrm{O}_{16}\right)$ can precipitate, even if the precise mechanism of its formation is complex and not yet fully understood (Grangeon et al., 2015). The reverse reaction $\left(\mathrm{Mn}^{3+} \rightarrow \mathrm{Mn}^{2+}\right)$ is theoretically possible but little information exists on it, and the preservation of "old" ${ }^{40} \mathrm{Ar}-{ }^{39} \mathrm{Ar}$ ages in loose surface blocks, dismantled crusts and/or laminae within complex botryoids (e.g. 
Hénocque et al., 1998, Beauvais et al., 2008, De Putter et al., 2015), suggests that it is never complete and that Mn oxides, once formed, may be relatively resistant to hydrolysis.

The different processes briefly outlined above therefore require an exposed landmass, an aerated zone, mildly acidic water and oxygen, in order to transform primary reduced ore into supergene manganese oxides (or any other secondary oxidized ore; see Fontaine et al., 2020). This means that weathering and the formation of manganese oxides will not proceed in lowlying and waterlogged environments, nor in uplifted/exposed settings with no meteoric fluids (rainwater) input, as in arid settings. Further links between weathering and climate are discussed in section 4 .

\section{Tectonic context of supergene ore formation at Kasekelesa and Mwene-Ditu}

Age frequency histograms of validated ages for Kasekelesa (Fig. 2, left) and Mwene-Ditu (Fig. 2, right) reveal a complex sequence of events starting possibly as early as the Albian, but more certainly in the Campanian.

The occurrence of an Albian or older radiogenic component at Kasekelesa is suggested by the fusion steps recorded for two analyses for sample RGM $2230(\gamma, \delta)($ Fig. 4). The validity of this assumption is arguable based on ${ }^{40} \mathrm{Ar} /{ }^{39} \mathrm{Ar}$ results alone, but an Albian denudation event $(\sim 110 \mathrm{Ma})$ is also suggested by fission track analysis results for a pegmatite at Manono, c. $450 \mathrm{~km}$ NE to Kasekelesa (S. Dewaele, UGent, unpubl. data). This would suggest that the study area at large was already uplifted and exposed to weathering at the end of the Lower Cretaceous.

The oldest reliable age obtained by the present study, again for Kasekelesa, is Campanian, at c. $76.5 \mathrm{Ma}$ (Fig. 2a). The greater length of the record at Kasekelesa than at Mwene-Ditu is explained by the position of these localities within the Congo Basin (Fig. 11). Mwene-Ditu is located more basinward than Kasekelesa, as well as Kisenge, and was covered during the 
Upper Mesozoic by Cretaceous sediments (Lepersonne, 1974), whose age is now confined to younger than c. $79( \pm 6.8)$ to $113 \mathrm{Ma}$, based on the age of detrital zircons from Kwango Group deposits of the Mwene-Ditu area (Roberts et al., 2015). In this area, the Mesozoic deposits are locally overlain by Kalahari sands, of probable Paleogene age (Giresse, 2005; Linol et al., 2015a), implying a further limitation of the period during which primary manganese deposits could be exposed. At the more southern localities of Kasekelesa and Kisenge, no Mesozoic sediment cover seems to have occurred. The greater length of the record at Kasekelesa than at Kisenge can be attributed to the position of Kasekelesa, in the immediate vicinity of the Neoproterozoic Katanga plateau, allowing preservation of the record of events which have elsewhere been eroded or never developed.

Compressional events caused a marked uplift of southern Katanga from the end of the Mesozoic onward (see Kipata et al., 2013). This episode probably prevented deposition of Upper Mesozoic sediments in this uplifted area and on its proximal shoulder, while favouring the formation of lateritic duricrusts on the uplifted area (Alexandre, 2002) and the formation of large river systems flowing northwest into the Congo Basin (Roberts et al., 2012 \& 2015; Owusu Agiemang et al., 2016). This Upper Mesozoic (Santonian) uplift resulted from an intense short-lived continent-wide deformation episode and relief-forming event that has been attributed to the collision of Arabia with a Tethyan arc. It follows the Marion plume development (c. 92-84 Ma, Torsvik et al., 1998) and would be synchronous with the emplacement of various kimberlites, in Southern Africa and in the DR Congo (86-79 Ma) (Burke \& Gunnell, 2008).

The Campanian ${ }^{40} \mathrm{Ar} /{ }^{39} \mathrm{Ar}$ age (c. $76.5 \mathrm{Ma}$ ) recorded for Kasekelesa yields the oldest reliable age for supergene Mn ore formation on an uplifted and exposed landmass for the African continent (Fig. 12a). It is roughly contemporaneous with an Upper Cretaceous (80-70 Ma) weathering episode identified at Léro in Guinea, based on paleomagnetic data (Théveniaut, 
2012). A similar Campanian age $(77.0 \pm 7.5 \mathrm{Ma})$ was obtained for assumed supergene apatite, dated with U-Pb method, in the Kalahari Manganese Field, again recording an episode of chemical weathering along an exposed landmass during the Upper Cretaceous (Vafeas et al., 2018a \& b).

These coeval supergene deposits support the hypothesis of an extensive subcontinental etchplain, possibly pertaining to the vast "African Erosion Surface" that has been inferred for the region (see e.g. Burke \& Gunnell, 2008; Guillocheau et al., 2018). The present study suggests that the development of this surface already started in the Upper Cretaceous (Fig. 12a), at least $20 \mathrm{Ma}$ before current estimates (Guillocheau et al., 2018). However, according to Burke \& Gunnell (2008), the "African Erosion Surface" was a composite feature, generated during a long cycle of erosion, initiated at c. $180 \mathrm{Ma}$, fully established at c. $125 \mathrm{Ma}$, and ending at c. $30 \mathrm{Ma}$. This would accommodate the suspected Albian and assured Campanian events of supergene Mn ore formation recorded for Kasekelesa.

It is worth mentioning that the vast mantled etchplain domain sketched in Fig. 12a mimics fairly well the contour lines of large cratonic masses (West African Craton, Congo-TanzaniaBangweulu Craton and Kalahari Craton, the latter two connected by the Damaran-Lufilian orogen), as they were assembled from c. $600 \mathrm{Ma}$ onward and as they appear today, using geophysics and tomographic models (Begg et al., 2009).

The oldest Cenozoic event detected at Kasekelesa, dating from the Paleocene (Selandian, c. 59.6 Ma; Fig. 2), may also be attributed to this long "African Erosion Surface" stage. The continental scale of this event is supported by its correlation with the oldest phase of supergene Mn ore formation observed at Tambao, Burkina Faso (Colin et al., 2005; Beauvais et al. 2008). This could correspond to the onset of a 60-40 Ma interval, when Central Africa became a vast mantled etchplain with a gentle westward slope, still part of the African Erosion Surface (Guillocheau et al., 2018). 
The next recorded event is a major Middle Eocene (Lutetian, c. 45 Ma; Fig. 2) episode of supergene ore formation. It is again detected only for Kasekelesa, at a stage when Kalahari Group sediments were being deposited in the Congo Basin (Fig. 11), preventing the development of a comparable record at Mwene-Ditu. This Lutetian event was initiated somewhat earlier at Tambao, where a long period of weathering occurred, extending from the late Ypresian to the middle Lutetian (c. 50 to $44 \mathrm{Ma}$ ) (Hénocque et al., 1998; Colin et al. 2005; Beauvais et al., 2008).

The next event recorded for Kasekelesa is Late Eocene in age (Priabonian,c. 35 Ma; Fig 2). It is also recognized for Mwene-Ditu, where it is less conspicuous but where it represents the oldest recorded event (Fig. 2). This Priabonian episode may correspond to the uplift of the East African Plateau (EAP), attributed to mantle upwelling (Ebinger et al., 1993; Wichura et al., 2010; Guillocheau et al., 2018). The recognition of this event at Mwene-Ditu, located within the Congo Basin, could indicate that EAP uplift resulted in erosion proceeding basinward, exposing areas previously covered by sediments (Figs 11 \& 12). A Priabonian event is also known for Tambao (Colin et al., 2005; Beauvais et al., 2008), in a part of Africa for which doming, attributed to magmatic activity, has been recognized to start in the Middle Eocene (Reusch et al., 2010 \& 2011; Guillocheau et al., 2018; Fig. 12).

The next period of supergene ore formation occurred around the Oligo-Miocene boundary, both at Kasekelesa (c. 23.8 Ma) and at Mwene-Ditu (c. 22.4 Ma) (Fig. 2). These ages document ongoing weathering in a vast uplifted area, comprising the EAP and the southeastern margins of the Congo Basin (Fig. 12b). EAP uplift resulted in a major period of erosion that seems to have affected the entire Congo Basin, as suggested by massive accumulation of sediments in the offshore Congo fan (Lavier et al., 2001; Anka et al., 2009 \& 2010; Venancio da Silva et al., 2019). Around the same time, a major episode of chemical weathering occurred at Tambao (Colin et al., 2005; Beauvais et al. 2008). This took place at 
the end of the Oligocene (Chattian), reaching its paroxysm at c. $24.4 \mathrm{Ma}$, followed by a major period of erosion (c. 24 to $18 \mathrm{Ma}$ ).

The Mio-Pliocene age records for Kasekelesa and Mwene-Ditu (Fig. 2) comprise several events, as previously also recorded for Kisenge (De Putter et al., 2015). All three sites were therefore adequately exposed during this time interval. The three studied sites record extensive supergene ore formation during the Langhian-Serravallian (Middle Miocene), with ages of c. $15.4 \mathrm{Ma}$ and c. $13.3 \mathrm{Ma}$ at Kasekelesa(Fig. 2), c. $15 \mathrm{Ma}$ at Mwene-Ditu(Fig. 3), and c. 15.7 Ma, c. 14.2 Ma and c. 13.6 Ma at Kisenge (De Putter et al., 2015). For Kasekelesa and Kisenge, these results record two clearly distinct successive periods of weathering, with Langhian (c. $15.5 \mathrm{Ma}$ ) and Serravallian (c. $13.4 \mathrm{Ma}$ ) ages. A similar dual event is also recorded at Tambao, with slightly younger Langhian and Serravallian components (c. 14.5$15 \mathrm{Ma}$, c. $12.6 \mathrm{Ma}$; Beauvais et al., 2008), and it may also have been recognized for a locality in South Africa (Van Niekerk et al., 1999).

In the Late Miocene, supergene ore formation is clearly recorded for the Tortonian stage at Kisenge (c. 10.5 Ma; De Putter et al., 2015), but this event is only suspected at Kasekelesa and Mwene-Ditu. Outside Central Africa, a Tortonian event has been inferred for the Kalahari Manganese Field (Gutzmer et al., 2012), but not for West Africa. For the Messinian stage, a weathering event is recorded at Mwene-Ditu (7.2-5.6 Ma), but it is lacking at Kasekelesa and Kisenge. Similar ages seem to have been detected in the Kalahari Manganese Field (Gutzmer et al., 2012) and they have been clearly recognized for West Africa (7.25.8 Ma; Beauvais et al., 2008). These variations between different parts of Africa during the Late Miocene, with only scattered known localities of supergene manganese ore formation, suggest a lack of continent-wide control on the development and preservation of weathering profiles. They may also result from non-tectonic processes, such as the climatic context which is further examined in the next section. 
In contrast to the Miocene, the Pliocene is prominently represented in the age record for Mwene-Ditu (Fig. 2). Pliocene ages have previously also been obtained for Kisenge (Decrée et al., 2010; De Putter et al., 2015), as well as for the Kalahari Manganese Field (Gutzmer et al., 2012) and Tambao (Beauvais et al., 2008). The absence of Pliocene (and Messinian) ages in the Kasekelesa record is currently not understood and could result from local conditions, assuming the available age record is complete. The site is adjacent to the steep shoulder of the high plateau of south-eastern Katanga (Fig. 11), and could have been buried beneath a sediment cover during this interval later removed by Quaternary valley incision and erosion. A similar mechanism has been proposed for the adjacent Katanga plateau (Decrée et al., 2010).

\section{Paleoclimatic conditions}

The previous section dealt with the tectonic context of supergene ore formation, registered by the ${ }^{40} \mathrm{Ar} /{ }^{39} \mathrm{Ar}$ age record for the study area. Another factor to be considered is paleoclimate, as leaching, in an environment with sufficient rainfall, is a prerequisite for this type of secondary ore development (see also Section 2). The Meso-Cenozoic climate record of Central Africa is not yet adequately known but the ${ }^{40} \mathrm{Ar} /{ }^{39} \mathrm{Ar}$ age record on the studied sites is relevant to bring additional information and/or constraints. One indication for a relationship between supergene ore formation in the study area and global climate is the recognition that similar ores formed at the same time in other parts of the world. Restricting the overview to examples from the southern hemisphere, this is mainly the case for:

- the Late Cretaceous to Middle Eocene, which has also been recorded for Brazil (from

c. 70 to c. 40 Ma; Vasconcelos et al., 1994; Ruffet et al., 1996; Vasconcelos \& Carmo, 2018), Australia (from at least c. 65 to c. $44 \mathrm{Ma}$; Vasconcelos et al., 2013), and southern India (possibly from at least c. 50 Ma to c. $45 \mathrm{Ma}$; Bonnet et al., 2016). 
- the Late Eocene (Priabonian), recorded for Brazil (Vasconcelos et al., 1994; Ruffet et al., 1996; Vasconcelos \& Carmo, 2018), southern India (Bonnet et al., 2016), and possibly Australia (Vasconcelos et al., 2013).

- the Late Oligocene, recorded for Brazil (Carajas, Amazonia; Vasconcelos et al., 1994), southern India (Bonnet et al., 2016) and Australia (in Queensland by Li \& Vasconcelos (2002) and in northwest Australia by Vasconcelos et al. (2013)).

- the Early to Middle Miocene Burdigalian-Langhian K-Mn ages (16.5-16 Ma) are recorded for South America, on the weathered Second Paraná Plateau (Paraná State, Brazil) (Riffel et al., 2014)) but with no evidence of a Serravallian weathering event, as it also seems to be the case for Carajas (Amazonia, Brazil) (Vasconcelos et al., 1994). In contrast and somewhat surprisingly, a young Serravallian weathering event (c. $12 \mathrm{Ma}$ ) seems attested for south-eastern Brazil (Carmo and Vasconcelos, 2004, 2006; Vasconcelos \& Carmo, 2018) but without any evidence of a Langhian one. BurdigalianLanghian records are reported for Queensland (Australia) by Li and Vasconcelos (2002) and Vasconcelos and Conroy (2003) and for north-western Australia by Vasconcelos et al. (2013) but, as previously, without any evidence of a Serravallian one.

Section 2 above summarizes the link between exposed areas and chemical weathering of manganese ore. In more general terms, the coupling between weathering and climate is complex and relates to $\mathrm{CO}_{2}$ global budget. Weathering indeed consumes gaseous $\mathrm{CO}_{2}$ and precipitates carbonates, most generally far away from the weathering site (a.o. in the ocean), along:

(4) $\mathrm{CaSiO}_{3(\mathrm{~s})}+2 \mathrm{CO}_{2(\mathrm{~g})}+\mathrm{H}_{2} \mathrm{O} \rightarrow \mathrm{Ca}^{2+}{ }_{(\mathrm{aq})}+2 \mathrm{HCO}_{3}^{-}(\mathrm{aq})+\mathrm{SiO}_{2}$

or

(5) $\mathrm{CaCO}_{3(\mathrm{~s})}+\mathrm{CO}_{2(\mathrm{~g})}+\mathrm{H}_{2} \mathrm{O} \rightarrow \mathrm{Ca}^{2+}{ }_{(\mathrm{aq})}+2 \mathrm{HCO}_{3}{ }^{-}$(aq)

where $\mathrm{CaSiO}_{3}$ is taken, in reaction 4, as a type mineral for all silicates (Beaulieu et al., 2012). 
Global climate is therefore regulated by a negative feedback between atmospheric $\mathrm{CO}_{2}$ level and chemical weathering of exposed landmasses, over geological time scales (Maher \& Chamberlain, 2014). With elevated altitudes in Central Africa at the turn of the Lower to Upper Cretaceous (Sahagian, 1988; Burke \& Gunnell, 2008) and simultaneous high level of atmospheric $\mathrm{CO}_{2}$ (Bice \& Norris, 2002; Wang et al., 2014), weathering in this region heavily depends on rainfall runoff, which is a function of global/local climate (Maher \& Chamberlain, 2014). It seems likely that long-term weathering on high altitudinal (Central) Africa is somehow involved in the overall progressive cooling of the climate from the Turonian to the Maastrichtian period.

Within this global context, our supergene Mn-ore formation events recorded for Central Africa (Katanga, Mwene-Ditu, Kisenge) were accurately positioned on an updated global $\delta^{18} \mathrm{O}$ curve(Fig. 13). Caution is required as this approach compares "absolute" isotopic and relative chronostratigraphic ages (see caption of Fig. 13 for explanations).This is done, using the $\delta^{18} \mathrm{O}$ curve of Friedrich et al. (2012), with updated (see inserts) Campanian and Paleocene stages according to the report by Gradstein et al. (2012). This exercise suggests that supergene ore formation in the study area did not arise during climatic optima (Fig. 13). This decoupling is apparent for the Campanian, but it is most striking for the long-lasting (c. $60 \mathrm{Ma}$ down to c. $50 \mathrm{Ma}$ ) early Cenozoic warm period (Zachos et al., 2001, 2008) which culminated in the Early Eocene Climatic Optimum (EECO; c.50-52 Ma, in Chron C23n). The Kasekelesa ages (c. 76 , c. 60 , c. 45 , c. $35 \mathrm{Ma}$ ) record supergene ore formation during the following episodes:

- during the relatively cold Campanian which followed the warm lower and middle Cretaceous period; 
- at the onset and end of the warm late Paleocene to Middle Eocene period with its succession of short-lived episodes of global warming (Fig.13: ELPE, PETM, ETM2) (e.g. Zachos et al., 2010; Feakins \& deMenocal, 2010);

- at the end of the Eocene (Priabonian), preceding the Eocene-Oligocene Stehlin's "Grande Coupure" (Stehlin, 1910) and the major oxygen isotope (Oi-1) Oligocene event (Miller et al., 1991).

In further details, the Selandian (c. $60 \mathrm{Ma}$ ) and Lutetian (c. $45 \mathrm{Ma}$ ) ${ }^{40} \mathrm{Ar} /{ }^{39} \mathrm{Ar}$ age record bracket the late Paleocene - early Eocene hyperthermals sequence: Early Late Paleocene Event (ELPE) at c. $59.5 \mathrm{Ma}$ (see caption of Fig. 13); Paleocene-Eocene Thermal Maximum (PETM) at c. $56 \mathrm{Ma}$; Eocene Thermal Maximum 2 (ETM2) at c. $53.7 \mathrm{Ma}$ ); the Early Eocene Climatic Optimum (EECO) at c. 50-52 Ma and subsequent return to normal towards colder climatic conditions. To the onset of the sequence, the recorded Selandian event fully matches in time with the Early Late Paleocene Event (ELPE), which is associated with a significant change in ocean deep-water circulation (Bralower et al., 2002), and initiates the long-lasting warming trend in the late Paleocene and early Eocene. But subsequently, no ages are recorded in this warm [60 - 45 Ma] interval, in which the Congo Basin and its marine outlet experienced basin starvation, condensed sedimentation and a drastic decrease in faunal diversity (Anka et al., 2010; Linol et al., 2015b; Solé et al., 2018). The record resumes in the Lutetian and later on, in the Priabonian (c. $35 \mathrm{Ma}$ ), when the world climate experienced a prolonged shift toward the colder Neogene.

Selandian (c. $60 \mathrm{Ma}$ ) and Lutetian (c. $45 \mathrm{Ma}$ ) supergene ore formation has also been recognized for Tambao (Hénocque et al., 1998; Colin et al. 2005; Beauvais et al., 2008; c. $59 \mathrm{Ma} \&$ c. $44 \mathrm{Ma}$ ) where, after the EECO (c. 50-52 Ma), the middle Eocene age record starts somewhat earlier, during the late Ypresian (at c. $50 \mathrm{Ma}$ ) when the shift towards colder climatic conditions begins, and continues until c. 44 Ma. This concomitance, on a continental 
scale, suggests that the climate was favourable for supergene Mn ore formation throughout a vast portion of Africa at least during the Lutetian, and later on, in the Priabonian (see above). As aforementioned, it is likely that a part of this long interval (c. 76 to c. $35 \mathrm{Ma}$ ) coincides with the major planation episode of the "African Erosion Surface" - which might not be entirely synchronous in all parts of Africa (Burke \& Gunnell, 2008). During the Paleogene, Central Africa occupied tropical paleolatitudes (Torsvik et al., 2012). From the Late Cretaceous (c. $77 \mathrm{Ma}$ ) to the Early Paleocene (c. $65 \mathrm{Ma}$ ), it experienced stable climatic conditions, with savannah-type woodland over most of the study area (Plana, 2004). The climate was more seasonal between c. 65 and $46 \mathrm{Ma}$, with a mosaic of rainforest and savannah over most of the present-day Congo Basin (Plana, 2004). Considering only climate as factor, conditions seem to have been unfavourable for supergene ore formation during this warm period, centred around the Early Eocene Climatic Optimum of c. 50-52 Ma.

During the same period, bauxite is assumed to have formed throughout Africa (Tardy et al., 1991; Chardon et al., 2006; Burke \& Gunnell, 2008; Butt \& Bristow, 2012; Guillocheau et al., 2015).The widespread formation of residual $\mathrm{Al}$ deposits and supergene $\mathrm{Mn}$ ores requires sufficient rainfall, which is compatible with a seasonal climate pattern before or after the warm EECO (c. 50-52 Ma), at c. $60 \mathrm{Ma}$ or in the time range c. 50-44 Ma (Fig. 13). In the vicinity of the study area, the Lutetian Mahenge flora in Tanzania (c. $46 \mathrm{Ma}$ ) points to woodlands which suggest a seasonally dry climate, in a time of global warm conditions (Jacobs et al., 2010).

In the Neogene, conditions were very different from those prevailing during the Paleogene, due to (i) the development of the Antarctic Circumpolar Current, favoured by the opening of the Drake passage, causing continent-wide glaciation in Antarctica from the Oligocene Oi-1 glaciation onwards (Fig. 13), (ii) the northward shift of Central Africa towards an equatorial position, and (iii) the development of the present-day climate pattern, with the Central 
African Rift acting as a North-South-oriented divide (Maley, 1996; Plana, 2004; Wade \& Pälike, 2004; Feakins \& deMenocal, 2010; Torsvik et al., 2012). The lack of Oligocene ages for supergene ore formation in Central Africa, except Late Chattian (at Kasekelesa), is consistent with arid conditions prevailing within the Congo Basin at that time, as recorded by the deposition of Kalahari Group sands (Maley, 1996; Linol et al., 2015b).

The Late Chattian event identified for Kasekelesa (c. $23.8 \mathrm{Ma}$ ), which has also been recognized in West Africa (Beauvais et al. 2008) and possibly also in South Africa (Gutzmer et al., 2012) was also recognized for Brazil (Vasconcelos et al., 1994). It coincides with the paroxysm of late Oligocene warming, predating the global Mi-1 glaciation (Fig. 13) (Zachos et al., 2001). The corresponding event at Mwene Ditu is Aquitanian in age (c. 22.4 Ma), about 1.3 Ma younger than at Kasekelesa, suggesting that sufficiently humid conditions for supergene ore development prevailed at that time, after the Mi-1 glaciation.

The Middle Miocene Langhian events (c. 15.8 Ma to c. $14.3 \mathrm{Ma}$ ) that are recognized for the study area, as well as for West Africa (Hénocque et al., 1998; Colin et al., 2005; Beauvais et al., 2008) and possibly for South Africa (Van Niekerk et al., 1999) are also identified in South America (Riffel et al., 2014; Vasconcelos et al., 1994) or in Australia (Li \& Vasconcelos, 2002; Vasconcelos \& Conroy, 2003). They may be linked to the Mid Miocene Climatic Optimum ( 17-15 Ma; Flower \& Kennett, 1994; Zachos et al., 2001; Henrot et al., 2017). Surprisingly, this event was not registered in South India (Bonnet el al.; 2016).

Next, aridity increased in the southwestern part of Africa during the Mio-Pliocene, due to changes in the Benguela upwelling patterns, which strengthened equator-to-pole temperature gradients, while West Africa passed from equatorial to tropical paleolatitudes (Maley, 1996; Feakins \& deMenocal, 2010; Torsvik et al., 2012). In these conditions, supergene ore formation took place at multiple locations, including several that are recognized both for Central Africa and for South Africa ( 16 to $13 \mathrm{Ma}, \sim 10 \mathrm{Ma}$, and $\sim 5$ to $2.5 \mathrm{Ma}$; Van Niekerk 
et al., 1999; Gutzmer et al., 2012; De Putter et al., 2015; this study). Overall, this part of the record for Central Africa developed in the course of a global cooling trend, starting after the Mid-Miocene Climatic Optimum, with widespread forested conditions giving way to mixed grassland and forest (Feakins \&deMenocal, 2010; Jacobs et al., 2010). Dry climates prevail in tropical Africa from the Miocene onwards, but with transient moist episodes in the Early Pliocene (c. $5 \mathrm{Ma}$ - c. $3.5 \mathrm{Ma}$; Plana, 2004), which may correspond to the Late Neogene ages obtained for Mwene-Ditu (Fig. 3) and Kisenge (De Putter et al., 2015).

West Africa, through the work carried out on the Tambao (Burkina Faso) Mn-ore deposit, appears to record a dense series of weathering periods from late Burdigalian to Pliocene (Hénocque et al., 1998; Colin et al., 2005, Beauvais et al., 2008), at $18 \mathrm{Ma}$; 15-14.5 Ma; 12.7 to $11.5 \mathrm{Ma}$; 7.2 to $5.8 \mathrm{Ma}$; and 3.4 to $2.9 \mathrm{Ma}$ (Beauvais et al., 2008). Several of these weathering periods differ significantly (e.g. the $\sim 18 \mathrm{Ma}, 12.7-11.5 \mathrm{Ma}$ and $7.2-5.8 \mathrm{Ma}$ events) from the intervals defined for Central and Southern Africa. Nevertheless, in the absence of additional studies (currently ongoing) on the West African domain, it is premature to go further into the comparisons.

\section{Conclusion}

The timing of supergene manganese ore formation in the south-east of the D.R. Congo, as recorded by ${ }^{40} \mathrm{Ar} /{ }^{39} \mathrm{Ar}$ ages, has implications for understanding the tectono-climatic evolution of a vast part of Africa, at a local to continent-wide scale.

At the local scale, the ages document the formation of supergene Mn ores, most likely synchronous with the development of other supergene ores $(\mathrm{Cu}, \mathrm{Co})$ and residual ores $(\mathrm{Fe}$, Al), on a stable uplifted substrate which was exposed to the atmosphere (Alexandre, 2002; Decrée et al., 2010; De Putter et al., 2010, 2015; Fontaine et al., 2020). Such conditions occurred repeatedly on the Katanga plateau and the neighbouring East African Plateau, from 
at least $76 \mathrm{Ma}$ (Campanian) and possibly $110 \mathrm{Ma}$ (Albian) onward. The local geodynamic evolution is the result of a complex balance between erosion of the Late Proterozoic Lufilian range, compressive stresses generated at the southern active margin of Gondwana, and mantle upwelling that ultimately resulted in the opening of the East African Rift (Fig. 12). Strong regional uplift in the Eocene resulted in regressive erosion in the upstream Congo Basin, causing denudation of previously covered areas, including the Mwene-Ditu area (Kasai), where the age record starts in the Oligocene.

At the regional scale, the Campanian age (c. $76.5 \mathrm{Ma}$ ) obtained for a sample at Kasekelesa (Katanga) is the oldest ${ }^{40} \mathrm{Ar} /{ }^{39} \mathrm{Ar}$ age that has been recorded for supergene $\mathrm{Mn}$ ores from Africa. This Campanian event, contemporaneous with a weathering episode identified by other methods for Guinea (palaeomagnetism) and South Africa (U-Pb geochronology supergene apatite), records the existence of an etchplain surface which was older than 76.5 Ma, corresponding to the "African Erosion Surface”. This paleosurface, whose existence is here confirmed for the first time in Central Africa, might have covered much of Africa yet in the Middle Cretaceous (c. 100 Ma) (Fig. 12), but its occurrence is now at least confirmed for the Middle Campanian.

Continent-scale tectonics account for most of the periods of uplift, denudation and stability that are recorded by the ages of the analysed supergene manganese ores and they are therefore regarded as the first-order control for their development over the last $80 \mathrm{Ma}$ (Fig. 12). Climate is a second-order control, through the requirement that sufficient water needs to be available for supergene ore formation. The age record indicates that rainfall patterns were favourable for supergene ore formation during relatively cold periods, corresponding to the Upper Cretaceous, Paleocene, and Eocene (Fig. 13). No supergene Mn ore formation is recorded for most of the cold Oligocene, which was marked by arid conditions in the Congo Basin. In the Mio-Pliocene, supergene ore formation was favoured 
during transient humid episodes, as in the Early Miocene and Early Pliocene, or during climate optima, as the in the Middle Miocene (Fig. 13).

Age determination of supergene $\mathrm{Mn}$ ore formation proved to be a solid tool for determining the weathering and denudation history of parts of South America (Vasconcelos \& Carmo, 2018). Our ${ }^{40} \mathrm{Ar} /{ }^{39} \mathrm{Ar}$ age record for the south-eastern DRC confirms that this also applies to the Late Cretaceous to Neogene of Central Africa, which can be extended to other parts of the continent where similar age records are yet available or expected from work in progress.

\section{Acknowledgements}

This study is a contribution to the Paleurafrica research project (BR/121/A3/Paleurafrica) of the Belgian Science Policy Office (BELSPO). We are grateful to P.M. Vasconcelos and an anonymous reviewer for their constructive comments.

\section{References}

Alexandre J., 2002. Les cuirasses latéritiques et autres formations ferrugineuses tropicales Exemple du Haut-Katanga méridional. Annales du Musée Royal de l'Afrique Centrale, Sciences Géologiques 107, 118p.

Anka, Z., Séranne, M., Lopez, M., Scheck-Wenderoth, M., Savoye, B., 2009. The long-term evolution of the Congo deep-sea fan: A basin-wide view of the interaction between a giant submarine fan and a mature passive margin(ZaiAngo project). Tectonophysics 470, 42-56. 
Anka, Z., Séranne, M., di Primio, R., 2010. Evidence of a large upper Cretaceous depocentre across the Continent-Ocean boundary of the Congo-Angola basin. Implications for palaeodrainage and potential ultra-deep source rocks. Marine and Petroleum Geology 27, 301-611.

Beaulieu, E., Goddéris, Y., Donnadieu, Y., Labat, D., Roelandt, C., 2012. High sensitivity of the continental-weathering carbon dioxide sink to future climate change. Nature Climate Change, online publication DOI: 10.1038/NCLIMATE1419.

Beauvais, A., Chardon, D., 2013. Modes, tempo, and spatial variability of Cenozoic cratonic denudation: the West African example. Geochemistry, Geophysics, Geosystems 14, 15901608.

Beauvais, A., Ruffet, G., Hénocque, O., Colin, F., 2008. Chemical and physical erosion rhythms of the West African Cenozoic morphogenesis: the 39Ar-40Ar dating of supergene K-Mn oxides. Journal of Geophysical Research 113. F04007, 16 p.

Begg, G.C., Griffin, W.L., Natapov, L.M., O’Reilly, S.Y., Grand, S.P., O’Neill, C.J., Hronsky, J.M.A., Poudjom Djomani, Y., Swain, C.J., Deen, T., Bowden, P., 2009. The lithospheric architecture of Africa: seismic tomography, mantle petrology, and tectonic evolution. Geosphere 5, 23-50.

Berggren, W.A., Kent, D.V., Flynn, J.J., Van Couvering, J.A., 1985. Cenozoic Geochronology. Geological Society of America Bulletin 96, 1407-1418. 
Beukes, N.J., Swindell, E.P.W., Wabo, H., 2016. Manganese deposits of Africa. Episodes 39, 285-317.

Biagioni, C., Capalbo, C., Pasero, M., 2013. Nomenclature tunings in the hollandite supergroup. European Journal of Mineralogy 25, 85-90.

Bice, K.L., Norris, R.D., 2002. Possible atmospheric $\mathrm{CO}_{2}$ extremes of the Middle Cretaceous (late Albian-Turonian). Paleoceanography and Paleoclimatology 17, 22-1-22-17.

Bonnet, N.J., Beauvais, A., Arnaud, N., Chardon, D., Jayananda, M., 2016. Cenozoic lateritic weathering and erosion history of Peninsular India from ${ }^{40} \mathrm{Ar} /{ }^{39} \mathrm{Ar}$ dating of supergene $\mathrm{K}-\mathrm{Mn}$ oxides. Chemical Geology 446, 33-53.

Boven, A., Liégeois, J.P., He, H. Jang, J., Jelsma, H.A., Armstrong, R.A., 2011. The southern Kasai shield: a metacratonic boundary of the Congo craton? International Conference on Craton Formation and Destruction, 25-29 April 2011, Beijing, China.

Bralower, T.J., Premoli Silva, I., Malone, M.J., 2002. New evidence for abrupt climate change in the Cretaceous and Paleogene: an Ocean Drilling Program expedition to Shatsky Rise, northwest pacific. GSA Today 12 (11),November 2002, 4-10.

Burke, K., Gunnell, Y., 2008. The African Erosion Surface: a continental-scale synthesis of geomorphology, tectonics, and environmental change over the past 180 million years. Geological Society of America, Memoir 201, 66p. 
Butt, C.R.M, Bristow, A.P.J., 2012. Relief inversion in the geomorphological evolution of sub-Saharan West Africa. Geomorphology 185, 16-26.

Cahen, L., Lepersonne, J., 1967. The Precambrian of the Congo, Rwanda and Burundi. In Rankama, K. (ed.), The Precambrian. Volume 3. Wiley Interscience, New York, p. 143-290.

Cailteux J., De Putter Th., 2019. The Neoproterozoic Katanga Supergroup (D.R. Congo) : state-of-the-art and revisions of the lithostratigraphy, sedimentary basin and geodynamic evolution. Journal of African Earth Sciences 150, 522-531.

Cande, S.C., Kent, D.V. 1992. A new geomagnetic polarity time scale for the Late Cretaceous and Cenozoic. Journal of Geophysical Research 97, 13917-13951.

Carmo, I.D., Vasconcelos P.M., 2004. Geochronological evidence for pervasive Miocene weathering, Minas Gerais, Brazil. Earth Surface Processes and Landforms, 29/11, 1303-1320.

Carmo, I.D., Vasconcelos P.M., 2006. ${ }^{40} \mathrm{Ar} /{ }^{39} \mathrm{Ar}$ geochronology constraints on late Miocene weathering rates in Minas Gerais, Brazil. Earth and Planetary Science Letters, 241, 1-2, 8094.

Chardon, D., Chevillotte, V., Beauvais, A., Grandin, G., Boulangé, B., 2006. Planation, bauxites and epeirogeny: One or two paleosurfaces on the West African margin? Geomorphology 82, 273-282. 
Cheilletz , A., Ruffet, G., Marignac, C., Kolli, O., Gasquet, D., Féraud, G., Bouillin, J.P., 1999. ${ }^{40} \mathrm{Ar} /{ }^{39} \mathrm{Ar}$ dating of shear zones in the Variscan basement of the Greater Kabylia(Algeria). Evidence of an eo-Alpine event at $128 \mathrm{Ma}$ (Hauterivian-Barremian boundary): geodynamic consequences. Tectonophysics 306, 97-116.

Colin, F., Beauvais, A., Ruffet, G., Hénocque, O., 2005. First ${ }^{39} \mathrm{Ar}-{ }^{40} \mathrm{Ar}$ geochronology of lateritic manganiferous pisolites: implications for the Palaeogene history of a West African landscape. Earth and Planetary Science Letters 238, 172-188.

Cramer, B.S., Toggweiler, J.R., Wright, J.D., Katz, M.E., Miller, K.G., 2009. Ocean overturning since the Late Cretaceous: Inferences from a new benthic foraminiferal isotope compilation: Paleoceanography 24, PA4216.

Decrée S., Deloule E., Ruffet G., Dewaele S., Mees F., Marignac C., Yans J., De Putter Th., 2010. Geodynamics and climate controls in the formation of Mio-Pliocene world-class oxidized cobalt and manganese ores in the Katanga province, DR Congo. Mineralium Deposita 45, 621-629.

Deino A., Potts, R. 1992.Age-probability spectra for examination of single-crystal ${ }^{40} \mathrm{Ar} /{ }^{39} \mathrm{Ar}$ dating results: examples from Olorgesailie, southern Kenya rift. Quaternary International $13 / 14,47-53$.

De Putter, Th., Bernard, A., Perruchot, A., Nicaise, D., Dupuis, Ch., 2000. Low-temperature acid weathering in Newhaven, Sussex, and its application to theoretical modelling in radioactive waste-disposal sites. Clays and Clay Minerals 48, 238-246. 
De Putter, Th., Liégeois, J.P., Dewaele, S., Cailteux, J., Boyce, A., Mees, F., 2018. Paleoproterozoic manganese and base metals deposits at Kisenge-Kamata (Katanga, D.R. Congo). Ore Geology Reviews 96, 181-200.

De Putter, Th., Mees, F., Decrée, S., Dewaele, S., 2010. Malachite, an indicator of major Pliocene $\mathrm{Cu}$ remobilization in a karstic environment (Katanga, Democratic Republic of Congo). Ore Geology Reviews 38, 90-100.

De Putter, Th., Ruffet, G., Yans, J., Mees, F., 2015. The age of supergene manganese deposits in Katanga and its implication for the Neogene evolution of the African Great Lakes Region. Ore Geology Reviews 71, 350-362.

Decrée, S., Deloule, E., Ruffet, G., Dewaele, S., Mees, F., Marignac, C., Yans, J., De Putter, Th., 2010. Geodynamic and climate controls in the formation of Mio-Pliocene world-class oxidized cobalt and manganese ores in the Katanga Province, D.R. Congo. MineraliumDeposita 45, 621-629.

Duckworth, O.W., Martin, S.T., 2004. Role of molecular oxygen in the dissolution of siderite and rhodochrosite. Geochimica Cosmochimica Acta 68, 607-621.

Dumont, P., 1991. Problèmes de datation des surfaces d'aplanissement au Zaïre. Bulletin de la Société Géographique de Liège 27, 175-185. 
Ebinger, C.J., Yemane, T., Woldegabriel, G., Aronson, J.L., Walter, R.C., 1993. Late Eocene-Recent volcanism and faulting in the southern main Ethiopian rift. Journal of the Geological Society150, 99-108.

Feakins, S.J., deMenocal, P.B., 2010. Global and African regional climate during the Cenozoic. In L. Werdelin \& B. Sanders (eds), Cenozoic Mammals of Africa. University of California Press, Oakland, p. 45-55.

Feng Y.X., Vasconcelos, P.M., 2001. Quaternary continental weathering geochronology by laser-heating ${ }^{40} \mathrm{Ar} /{ }^{39} \mathrm{Ar}$ analysis of supergene cryptomelane. Geology 29/7, 635-638.

Fleck, R.J., Sutter, J.F., Elliot, D.H., 1977. Interpretation of discordant ${ }^{40} \mathrm{Ar} /{ }^{39} \mathrm{Ar}$ age-spectra of Mesozoic tholeiites from Antarctica. Geochimica Cosmochimica Acta 41, 15-32.

Flower, B.P., Kennett, J.P.,1994. The middle Miocene climatic transition: East Antarctic ice sheet development, deep ocean circulation and global carbon cycling. Palaeogeography, Palaeoclimatology, Palaeoecology 108, 537-555.

Foland, K. A., Hubacher, F. A., Arehart, G. B., 1992. ${ }^{40} \mathrm{Ar} /{ }^{39}$ Ar dating of very fined grained samples: an encapsulated-vial procedure to overcome the problem of ${ }^{39} \mathrm{Ar}$ recoil loss. Chemical Geology 102, 269-276.

Fontaine, L., De Putter, Th., Bernard, A., Decrée, S., Cailteux, J., Wouters, J., Yans, J., 2020.Complex mineralogical-geochemical sequences and weathering events in the supergene 
ore of the $\mathrm{Cu}-\mathrm{Co}$ Luiswishi deposit (Katanga, D.R. Congo). Journal of African Earth Sciences 161, https://doi.org/10.1016/j.jafrearsci.2019.103674

Friedrich, O., Norris, R.D., Erbacher, J., 2012. Evolution of middle to Late Cretaceous oceans - A 55 m.y. record of Earth's temperature and carbon cycle. Geology 40, 107-110.

Giresse, P., 2005. Meso-Cenozoic history of the Congo Basin. Journal of African Earth Sciences 43, 301-315.

Gradstein, F.M., Ogg, J.G., Smith, A.G., Agterberg, F.P.,Bleeker, W., Cooper, R.A., Davydov, V., Gibbard, P.,Hinnov, L.A., House, M.R. (†), Lourens, L., Luterbacher,H-P., McArthur, J., Melchin, M.J., Robb, L.J., Shergold,J., Villeneuve, M., Wardlaw, B.R., Ali, J., Brinkhuis, H.,Hilgen, F.J., Hooker, J., Howarth, R.J., Knoll, A.H.,Laskar, J., Monechi, S., Powell, J., Plumb, K.A., Raffi, I.,Röhl, U., Sanfilippo, A., Schmitz, B., Shackleton, N.J.,Shields, G.A., Strauss, H., Van Dam, J., Veizer, J., vanKolfschoten, Th., Wilson, D., 2004. A Geologic Time Scale 2004. Cambridge, 589 pp.

Gradstein, F.M., Ogg, J.G., Schmitz, M.D., Ogg, G.M., Agterberg, F.P., Anthonissen, D.E., Becker, T.R., Catt, J.A., Cooper, R.A., Davydov, V.I., Gradstein, S.R., Henderson, C.M., Hilgen, F.J., Hinnov, L.A., McArthur, J.M., Melchin, M.J., Narbonne, G.M., Paytan, A., Peng, S., Peucker-Ehrenbrink, B., Pillans, B., Saltzman, M.R., Simmons, M.D., Shields, G.A., Tanaka, K.L., Vandenberghe, N., Van Kranendonk, M.J., Zalasiewicz, J., Altermann, W., Babcock, L.E., Beard, B.L., Beu, A.G., Boyes, A.F., Cramer, B.D., Crutzen, P.J., van Dam, J.A., Gehling, J.G., Gibbard, P.L., Gray, E.T., Hammer, O., Hartmann, W.K., Hill, A.C., Hoffman, P.F., Hollis, C.J., Hooker, J.J., Howarth, R.J., Huang, C., Johnson, C.M., 
Kasting, J.F., Kerp, H., Korn, D., Krijgsman, W., Lourens, L.J., Mac-Gabhann, B.A., Maslin, M.A., Melezhik, V.A., Nutman, A.P., Papineau, D., Piller, W.E., Pirajno, F., Ravizza, G.E., Sadler, P.M., Speijer, R.P., Steffen, W., Thomas, E., Wardlaw, B.R., Wilson, D.S., and Xiao, S., 2012. The Geologic Time Scale 2012. Elsevier, Boston, 1176 pp.

Gradstein, F.M., Ogg, J.G., Hilgen F.J., 2012. On the Geologic Time Scale. Newsletters on Stratigraphy 45, 171-188.

Grangeon, S., Fernandez-Martinez, A., Warmont, F., Gloter, A., Marty, N., Poulain, A., Lanson, B., 2015. Cryptomelane formationfrom nanocrystalline vernadite precursor: a high energy $\mathrm{X}$-ray scattering and transmission electron microscopy perspective on reaction mechanisms. Geochemical Transactions 16:12; DOI 10.1186/s12932-015-0028-y

Green, D., Daly, M.C., 1982. Manganese mineralization in Zambia. Transactions of the Institution of Mining and Metallurgy B 91, 33-41.

Guillocheau, F., Chelalou, R., Linol, B., Dauteuil, O., Robin, C., Mvondo, F., Callec, Y., Colin, J.P., 2015. Cenozoic landscape evolution in and around the Congo Basin: Constraints from sediments and planation surfaces, In: de Wit, M.J., Guillocheau, F., de Wit, M.C.J. (eds.), Geology and Resource Potential of the Congo Basin. Springer, Berlin Heidelberg, p. 271-313. 
Guillocheau, F., Simon, B., Baby, G., Bessin, P., Robin, P., Dauteuil, O., 2018. Planation surfaces as a record of mantle dynamics : the case example of Africa. Gondwana Research $53,82-98$

Gutzmer, J., Du Plooy, A.D., Beukes, N.J., 2012. Timing of supergene enrichment of lowgrade sedimentary manganese ores in the Kalahari Manganese Field, South Africa. Ore Geology Review 47, 136-153.

Hanes, J.A., York, D., Hall, C.M., 1985. An ${ }^{40} \mathrm{Ar} /{ }^{39} \mathrm{Ar}$ geochronological and electron microprobe investigation of an Archean pyroxenite and its bearing on ancient atmospheric compositions. Canadian Journal of Earth Science 22, 947-958.

Harrison, T. M., 1983. Some observations on the interpretation of ${ }^{40} \mathrm{Ar} /{ }^{39} \mathrm{Ar}$ age spectra. Chemical Geology 1, 319-338.

Hautmann, S., Lippolt, H.J., 2000. ${ }^{40} \mathrm{Ar} /{ }^{39} \mathrm{Ar}$ dating of central European K-Mn oxides - a chronological framework of supergene alteration processes during the Neogene. Chemical Geology 170, 37-80.

Hénocque, O., Ruffet, G., Colin, F., Féraud, G., 1998. ${ }^{40} \mathrm{Ar} /{ }^{39} \mathrm{Ar}$ dating of West African lateritic cryptomelanes. Geochimica et CosmochimicaActa62, 2739-2756.

Henrot, A.-J.,Utescher, T., Erdei, B., Dury, M., Hamon, N., Ramstein, G., Krapp, M., Herold, N., Goldner, A., Favre, E., Munhoven, G., François, L., 2017. Middle Miocene climate and 
vegetation models and their validation with proxy data. Palaeogeography, Palaeoclimatology, Palaeoecology 467, 95-119.

Jacobs, B.F., Pan, A.D., Scotese, C.R., 2010. A review of the Cenozoic vegetation history of Africa. In L. Werdelin \& B. Sanders (eds), Cenozoic Mammals of Africa, University of California Press, Oakland, p. 57-72.

Kipata, M.L., Delvaux, D., Sebagenzi, M.N., Cailteux, J., Sintubin, M., 2013. Brittle tectonicand stress field evolution in the Pan-African Lufilian arc and its foreland (Katanga, DRC): from orogenic compression to extensional collapse, transpressional inversion and transition to rifting. Geologica Belgica 16, 1-17.

Lavier, L.L., Steckler, M.S., Brigaud, F., 2001. Climatic and tectonic control on the Cenozoic evolution of the West African margin. Marine Geology 178, 63-80.

Lee, J.-Y., Marti, K., Severinghaus, J.P., Kawamura, K., Yoo, H.-S., Lee, J.B., Kim, J.S., 2006. A redetermination of the isotopic abundances of atmospheric Ar. Geochimica et Cosmochimica Acta 70, 4507-4512.

Lepersonne, J., 1974. Carte Géologique du Zaïre au 1:2,000,000 et Notice Explicative. Direction de la Géologie, Département des Mines, République du Zaïre, 66 p.

Li, J.W., Vasconcelos, P., 2002. Cenozoic continental weathering and its implications for the palaeoclimate: evidence from ${ }^{40} \mathrm{Ar} /{ }^{39} \mathrm{Ar}$ geochronology of supergene $\mathrm{K}-\mathrm{Mn}$ oxides in $\mathrm{Mt}$ Tabor, central Queensland, Australia. Earth and Planetary Science Letters 200, 223-239. 
Liljestrand, H.M., 1985. Average rainwater $\mathrm{pH}$, concepts of atmospheric acidity, and buffering in open systems. Atmospheric Environment 19, 487-499.

Linol, B., de Wit, M.J., Barton, E., Guillocheau, F., de Wit, M.C.J., Colin, J.-P., 2015a. Facies analyses, chronostratigraphy and paleo-environmental reconstructions of Jurassic to Cretaceous sequences of the Congo Basin. In de Wit, M.J., Guillocheau, F., de Wit, M.C.J., (eds.), Geology and Resource Potential of the Congo Basin. Springer, Berlin, p. 135-161.

Linol, B., de Wit, M.J., Guillocheau, F., de Wit, M.C.J., Anka, Z., Colin, J.-P., 2015b. Formation and collapse of the Kalahari Duricrust ['African Surface'] across the Congo Basin, with implications for changes in rates of Cenozoic off-shore sedimentation. In de Wit, M.J., Guillocheau, F., de Wit, M.C.J., (eds.), Geology and Resource Potential of the Congo Basin, Springer, Berlin, p.,193-210.

Lippolt, H.J., Hautmann, S., $1995 .{ }^{40} \mathrm{Ar} /{ }^{39} \mathrm{Ar}$ ages of Precambrian manganese ore minerals from Sweden, India and Morocco, MineraliumDeposita 30, 246-256.

Maher, K., Chamberlain, C.P., 2014. Hydrologic regulation of chemical weathering and the geologic carbon cycle. Science 343, 1502-1504.

Maley, J.,1996. The African rain forest - main characteristics if change in vegetation and climate from the Upper Cretaceous to the Quaternary. In I.J. Alexander, M.D. Swaine \& R. Watling (eds.), Essays on the ecology of the Guinea-Congo Rain Forest. Proceedings of the Royal Society of Edinburgh B 104, 31-73. 
Miller, K. G., J. D. Wright, and R. G. Fairbanks, 1991. Unlocking the ice house: OligoceneMiocene oxygen isotopes, eustasy, and margin erosion, Journal of GeophysicalResearch 96, 6829-6848.

Morelli, B., Raucq, P., 1961. Lambeaux d'une série métamorphique manganésifère entre Mwene-Ditu et Luputa (Kasai). Bulletin de l'Académie Royale des Sciences d'Outre-Mer 7, 908-923.

Morelli, B., Raucq, P., 1962. Quartzites ferrugineux de Kanda-Kanda (Kasai, Congo). Annales de la Société Géologique de Belgique 85, 123-147.

Moureau, A., 1948. Kasekelesa. Unpublished UMHK-SudKat Report. Royal Museum for Central Africa Archives, Dossier SudKat II-A9.

Owusu Agyemang, P.C., Roberts, E.M., Jelsma, H.A., 2016. Late Jurassic-Cretaceous fluvial evolution of Central Africa: insights from the Kasai-Congo Basin, Democratic Republic Congo. Cretaceous Research 67, 25-43.

Pik, R., Marty, B., Carignan, J., Yirgu, G., Ayalew, T., 2008. Timing of East African Rift development in Southern Ethiopia: implication for mantle plume activity and evolution of topography. Geology 36, 167-170.

Plana, V., 2004. Mechanisms and tempo of evolution in the African Guineo-Congolian rainforest. Philosophical Transactions of the Royal Society London B, 359, 1585-1594. 
Renne, P.R., Balco, G., Ludwig, R.L., Mundil, R., Min, K., 2011. Response to the comment by W.H. Schwarz et al. on "Joint determination of ${ }^{40} \mathrm{~K}$ decay constants and ${ }^{40} \mathrm{Ar} * /^{40} \mathrm{~K}$ for the Fish Canyon sanidine standard, and improved accuracy for ${ }^{40} \mathrm{Ar} /{ }^{39} \mathrm{Ar}$ geochronology" by PR Renne et al. (2010). Geochimica et Cosmochimica Acta, 75, 5097-5100.

Renne, P.R., Mundil, R., Balco, G., Min, K., Ludwi, R.L., 2011. Joint determination of ${ }^{40} \mathrm{~K}$ decay constants and ${ }^{40} \mathrm{Ar} *{ }^{40} \mathrm{~K}$ for the Fish Canyon sanidine standard, and improved accuracy for ${ }^{40} \mathrm{Ar} /{ }^{39} \mathrm{Ar}$ geochronology. Geochimica et Cosmochimica Acta 74, 5349-5367.

Renne, P. R., Swisher, C. C., Deino, A. L., Karner, D. B., Owens, T. L., DePaolo, D. J., 1998. Intercalibration of standards, absolute ages and uncertainties in ${ }^{40} \mathrm{Ar} /{ }^{39} \mathrm{Ar}$ dating. Chemical Geology 145, 117-152.

Reusch, A., Nyblade, A., Wiens, D., Shore, P., Ateba, B., Tabod, C., Ngange, J., 2010. Upper mantle structure beneath Cameroon from body wave tomography and the origin of the Cameroon Volcanic Line. Geochemistry Geophysics Geosystems 11, Q10W07, 17p.

Reusch, A., Nyblade, A., Tibi, R., Wiens, D., Shore, P., Ateba, B., Tabod, C., Ngange, J., 2011. Mantle transition zone thickness beneath Cameroon: evidence for an upper mantle origin for the Cameroon Volcanic Line. Geophysical Journal International 187, 1146-1150.

Riffel, S., Vasconcelos, P., Carmo, I., Farley, K., 2014. Combined ${ }^{40} \operatorname{Ar}{ }^{39} \mathrm{Ar}$ and (U-Th)/He geochronological constraints on long-term landscape evolution of the Second Paraná Plateau and its ruiniform surface features, Paraná, Brazil. Geomorphology 233, 52-63. 
Roberts, E.M., Stevens, N.J., O'Connor, P.M., Dirks, P.H.G.M., Gottfried, M.D., Clyde, W.C., Armstrong, R.A., Kemp, A.I.S., Hemming, S., 2012. Initiation of the western branch of the East African Rift coeval with the eastern branch. Nature Geoscience 5, 289-294.

Roberts, E., Jelsma, H.A., Hegna, T., 2015. Mesozoic sedimentary cover sequences of the Congo Basin in the Kasai Region, Democratic Republic of Congo. In de Wit, M.J., Guillocheau, F., de Wit, M.C.J., (eds.), Geology and resource potential of the Congo Basin. Springer, Berlin, p. 163-191.

Roddick, J.C., Cliff, R.A., Rex D.C., 1980. The evolution of excess argon in alpine biotites A ${ }^{40} \mathrm{Ar}^{39} \mathrm{Ar}$ analysis. Earth and Planetary Science Letters 48, 185-208.

Ruffet, G., Féraud, G., Amouric, M., 1991. Comparison of ${ }^{40} \mathrm{Ar}-{ }^{39} \mathrm{Ar}$ conventional and laser dating of biotites from the North Trégor Batholith. Geochimica Cosmochimica Acta 55, $1675-1688$.

Ruffet, G., Féraud, G., Balèvre, M., Kiénast, J.-R., 1995. Plateau ages and excess argon in phengites: an ${ }^{40} \mathrm{Ar}-{ }^{39} \mathrm{Ar}$ laser probe study of Alpine micas (Sesia Zone, Western Alps, northern Italy). Chemical Geology 121, 327-343.

Ruffet, G., Gruau, G., Balèvre, M., Féraud, G., Philippot, P., 1997. Rb-Sr and ${ }^{40} \mathrm{Ar}^{-}{ }^{39} \mathrm{Ar}$ laser probe dating of high-pressure phengites from the Sesia zone (Western Alps): underscoring of excess argon and new age constraints on the high-pressure metamorphism. Chemical Geology 141, 1-18. 
Ruffet, G., Innocent, C., Michard, A., Féraud, G., Beauvais, A., Nahon, D., Hamelin, B., 1996. A geochronological ${ }^{40} \mathrm{Ar} /{ }^{39} \mathrm{Ar}$ and ${ }^{87} \mathrm{Rb} /{ }^{86} \mathrm{Sr}$ study of K-Mn oxides from the weathering sequence of Azul, Brazil. Geochimica et CosmochimicaActa 60, 2219-2232.

Sahagian, D., 1988. Epeirogenic motions of Africa as inferred from Cretaceous shoreline deposits. Tectonics 7, 125-138.

Schmitt, J.-M., 1999. Weathering, rainwater and atmosphere chemistry: example and modelling of granite weathering in present conditions, in a $\mathrm{CO}_{2}$-rich, and in an anoxic palaeoatmosphere. Special Publications of the International Association of Sedimentologists $27,21-41$

Schuiling, H., 1955. Kasekelesa. Unpublished UMHK-SudKat Report. Royal Museum for Central Africa Archives, Dossier SudKat II-A9

Solé, F., Noiret, C., Desmares, D. Adnet S., Taverne, L., De Putter, Th., Mees, F., Yans, J., Steeman, T., Louwye, S., Folie, A., Stevens, N.J., Gunnell, G.F., Baudet, D., Kitambala Yaya, N., Smith, Th., 2019. Reassessment of historical sections from the Paleogene marine margin of the Congo Basin reveals the absence of Danian deposits. Geoscience Frontiers 10, 1039-1063.

Stehlin, H.G., 1910. Remarques sur les faunules de Mammifères des couches éocènes et oligocènes du Bassin de Paris. Bulletin de la Société Géologique de France, vol. 4, nº 9, 488520. 
Tardy, Y., Kobilsek, B., Paquet, H., 1991. Mineralogical composition and geographical distribution of African and Brazilian periatlantic laterites. The influence of continental drift and tropical paleoclimates during the past 150 million years and implications for India and Australia. Journal of African Earth Sciences 12, 283-295.

Theveniaut, H., 2012. Recherches et applications du paléomagnétisme et du magnétisme des roches aux problématiques d'un service géologique national. Unpublished $\mathrm{PhD}$ dissertation Orléans University, France.

Torsvik, T.H., Tucker, R.D., Ashwal, L.D., Eide, E.A., Rakotosolofo, N.A., deWit, M.J., 1998. Late Cretaceous magmatism in Madagascar: palaeomagnetic evidence for a stationary Marion hotspot. Earth Planetary Science Letters 164: 221-232.

Torsvik, T.H., Van der Voo, R., Preeden, U., Mac Niocaill, C., Steinberger, B., Doubrovine, P.V., van Hinsbergen, D.J.J., Domeier, M., Gaina, C., Tovher, E., Meert, J.G., McCausland, P.J., Cocks, L.R.M., 2012. Phanerozoic polar wander, paleogeography and dynamics. EarthScience Reviews 114, 325-368.

Turner, G., 1971. ${ }^{40} \mathrm{Ar}-{ }^{39} \mathrm{Ar}$ ages from the lunar Maria. Earth and Planetary Science Letters $11,169-191$.

Turner, G., Cadogan P. H., 1974. Possible effects of ${ }^{39} \mathrm{Ar}$ recoil in ${ }^{40} \mathrm{Ar}-{ }^{39} \mathrm{Ar}$ dating. Proceedings of the Fifth Lunar Science Conference 2, 1601 -1615 
Vafeas, N.A., Viljoen, K.S., Blignaut, L.C., 2018a. Mineralogical characterization of the thrusted manganese ore above the Blackridge Thrust Fault, Kalahari Manganese Field: the footprint of the Mukulu enrichment. Island Arc 2019;28:e12280; doi: 10.1111/iar.12280

Vafeas, N.A., Blignaut, L.C.,Viljoen, K.S., Meffre, S., 2018b. New evidence for the early onset of supergene alteration along the Kalahari unconformity. South African Journal of Geology 121, 157-170.

Van Niekerk, H.S., Gutzmer, J., Beukes, N.J., Philips, D., Kiviets, G.B., 1999. An ${ }^{40} \mathrm{Ar} /{ }^{39} \mathrm{Ar}$ age of supergene $\mathrm{K}-\mathrm{Mn}$ oxyhydroxides in a post-Gondwana soil profile on the Highveld of South Africa. South African Journal of Science 95, 450-454.

Vasconcelos, P.M., 1999. K-Ar and ${ }^{40} \mathrm{Ar}-{ }^{39} \mathrm{Ar}$ geochronology of weathering processes. Annual Review of Earth and Planetary Sciences 27, 83-229.

Vasconcelos, P.M., Becker, T.A., Renne,P.R.,Brimhall G.H., 1992. Age and duration of weathering by ${ }^{40} \mathrm{~K}-{ }^{40} \mathrm{Ar}$ and ${ }^{40} \mathrm{Ar} /{ }^{39} \mathrm{Ar}$ analysis of Potassium-Manganese Oxides, Science 58 , $451-455$.

Vasconcelos, P.M., Carmo, I de O., 2018. Calibrating denudation chronology through 40Ar/39Ar weathering chronology. Earth-Science Reviews 179, 411-435.

Vasconcelos, P.M., Conroy, M., 2003. Geochronology of weathering and landscape evolution, Dugald River valley, NW Queensland, Australia. Geochimica et CosmochimicaActa 67, 2913-2930. 
Vasconcelos, P., Heim, J., Farley, K., Monteiro, H., Waltenberg, K., 2013. ${ }^{40} \mathrm{Ar} /{ }^{39} \mathrm{Ar}$ and (U$\mathrm{Th}) / \mathrm{He}-{ }^{4} \mathrm{He} /{ }^{3} \mathrm{He}$ geochronology of landscape evolution and channel iron deposit genesis at Lynn Peak, Western Australia. Geochimica et CosmochimicaActa 117, 283-312.

Vasconcelos P.M., Renne, P.R., Becker, T.A., Wenk, H.R., 1995. Mechanisms and kinetics of atmospheric, radiogenic, and nucleogenic argon release from cryptomelane during ${ }^{40} \mathrm{Ar} /{ }^{39} \mathrm{Ar}$ analysis. Geochimica et CosmochimicaActa59, 2057-2070.

Vasconcelos P.M., Renne, P.R., Brimhall,G.H., Becker, T.A., 1994. Direct dating of weathering phenomena by ${ }^{40} \mathrm{Ar} /{ }^{39} \mathrm{Ar}$ and $\mathrm{K}-\mathrm{Ar}$ analysis of supergene $\mathrm{K}-\mathrm{Mn}$ oxides, Geochimica et CosmochimicaActa 58, 1635-1665.

Venancio da Silva, B., Hackspacher, P.C., Siqueira Ribeiro, M.C., Glasmacher, U.A., Gonçalves, A.O., Doranti-Tiritan, C., Françoso de Godoy, D., Constantino, R.R., 2019. Evolution of the Southwestern Angolan margin: episodic burial and exhumation is more realistic than long-term denudation. International Journal of Earth Sciences 108, 89-113.

Wade, B., Pälike, H., 2004. Oligocene climate dynamics. Paleoceanography, 19, PA4019, $16 \mathrm{p}$.

Wang, Y., Huang, C., Sun, B., Quan, C., Wu, J., Lin, Z., 2014. Paleo- $\mathrm{CO}_{2}$ variation trends and the Cretaceous greenhouse climate. Earth-Science Reviews 129, 136-147. 
Wichura, H., Bousquet, R., Oberhänsli, R., Strecker, M.R., Trauth, M.H., 2010. Evidence for middle Miocene uplift of the East African Plateau. Geology 38, 543-546.

Wijbrans, J.R., McDougall, I., 1986. ${ }^{40} \mathrm{Ar} /{ }^{39} \mathrm{Ar}$ dating of white micas from an Alpine highpressure metamorphic belt on Naxos (Greece): the resetting of the argon isotope system. Contributions to Mineralogy and Petrology 93, 187-194.

York, D.,1969. Least squares fitting of a straight line with correlated errors. Earth Planet. Science Letters 5, 320-324.

York, D., Evensen, N., Lopez-Martinez, M., De Basabe Delgado, J., 2005. Unified equations for the slope, intercept, and standard errors of the best straight line. American Journal of Physics 72(3), 367-375.

Zachos, J.C., Lohmann, K.C., Walker, J.C.G., Wise S.W., 1993. Abrupt climate change and transient climates during the Paleogene: a marine perspective. Journal of Geology 101, 191213.

Zachos, J.C., Pagani, M., Sloan, L., Thomas, E., Billups, K., 2001. Trends, rhythms, and aberrations in global climate 65 Ma to present. Science 292, 686-693.

Zachos, J.C., Dickens,G.R.,Zeebe, R.E., 2008. An early Cenozoic perspective on greenhouse warming and carbon-cycle dynamics. Nature 451, 279-283. 
Zachos, J.C., McCarren, H., Murphy, B., Röhl, U., Westerhold, T., 2010. Tempo and scale of Late Paleocene and Early Eocene carbon isotope cycles: implications for the origin of hyperthermals. Earth and Planetary Science Letters 299, 242-249.

\section{Figure captions}

Fig. 1. Geological map and location of studied manganese deposits (after Lepersonne, 1974).

Fig. 2. Kasekelesa (left) and Mwene-Ditu (right)

Lower part of the graphs: Frequency (probability density) diagram of apparent ages (ages of individual steps) of age spectra. White frequency diagrams for conventional age spectra, blue (Kasekelesa) or green (Mwene-Ditu) frequency diagrams for resized (30 steps) age spectra See text for explanations.

Upper part of the graphs: validated ages for Kasekelesa (blue) or Mwene-Ditu (green) with errors at the $1 \sigma$ level.Plateau ages (solid rounds), Pseudo-plateau ages (squares), Inverse isochron ages (triangles), Apparent ages pointed individually (empty circles).

Colour codes are those of the International Chronostratigraphic Chart.

Fig. 3. Kasekelesa: Campanian and Selandian ages.

- ${ }^{39} \mathrm{Ar}-{ }^{40} \mathrm{Ar}$ age spectra of Mn oxide samples. Apparent age error bars are at the $1 \sigma$ level; errors in the J-parameter are not included. Plateau and pseudo-plateau ages $(1 \sigma$ uncertainties including errors in the J-parameter) are given when applicable.Conventional age spectra (grey). Weighted age spectra (red). Resized age spectrum (blue). See text for explanations 
- Inverse isochron (correlation) diagram, with ${ }^{36} \mathrm{Ar} /{ }^{40} \mathrm{Ar}$ vs. ${ }^{39} \mathrm{Ar} /{ }^{40} \mathrm{Ar}$ (see text for explanation). Grey ellipses are excluded from isochron regression, MSWD stands for Mean Squares of Weighted Deviates.

- Frequency diagram of apparent ages of conventional (white) and resized (blue) age spectra (see text for explanation).

- Degassing diagram, presenting $\left({ }^{40} \mathrm{Ar} / \Delta \mathrm{V}_{\mathrm{T}^{\circ}}\right) /\left({ }^{40} \mathrm{Ar} / \Delta \mathrm{V}_{\mathrm{T}^{\circ}}\right)_{\mathrm{Max}}$ vs. $\%^{39} \mathrm{Ar}_{\mathrm{K}}$ (see text for explanation). $\Delta \mathrm{V}_{\mathrm{T}^{\circ}}$ corresponds to the laser power control voltage increment.

The colour codes of are those of the International Chronostratigraphic Chart.

Fig. 4. Kasekelesa: Lutetian and Priabonian ages. Refer to the legend of Figure 3 for explanations.

Fig. 5. Kasekelesa: Oligocene ages. Refer to the legend of Figure 3 for explanations.

Fig. 6. Kasekelesa: Miocene ages. Refer to the legend of Figure 3 for explanations.

Fig. 7. Mwene-Ditu: Early Miocene ages. Refer to the legend of Figure 3 for explanations. The resizing of age spectra was inoperative and is therefore not shown (samples RG 55584 and 55585 are now inventoried in the RMCA's sample collection with the numbers RGM 17279 and RGM 17280, respectively).

Fig. 8. Mwene-Ditu: Messinian ages. Refer to the legend of Figure 3for explanations. Frequency diagram of apparent ages of resized age spectra in green (samples RG 55557, 55587 and 55589 are now inventoried in the RMCA's sample collection with the numbers RGM 17276, RGM 17281 and RGM 17282, respectively). 
Fig. 9. Mwene-Ditu: Plio-Pleistocene ages. Refer to the legend of Figure 3for explanations. Frequency diagram of apparent ages of resized age spectra in green (samples RG 55562 and 55578 are now inventoried in the RMCA's sample collection with the numbers RGM 17277 and RGM 17278, respectively).

Fig. 10. Block diagram sketching the relationship between vertical movements of the landmass and weathering of Mn ore, in the Katanga-Kasai region. More info on the local Paleoproterozoic Mn-ore in De Putter et al. (2015; 2018). Below the oscillating water-table zone is a zone where another type of weathering occurs, in less oxidizing conditions and with sulphide ore (cementation; see Fontaine et al., 2020). Note that $\mathrm{H}_{2} \mathrm{CO}_{3(\mathrm{aq})}$ actually dissociates in $\mathrm{H}^{+}$and $\mathrm{HCO}_{3}{ }^{-}$within the aerated zone (see text for further comments).

Fig. 11. Conditions along the NNW-SSE profile shown in Figure 1 during two different periods (dashed line joining Kasekelesa to Mwene-Ditu deposits). A. Campanian, with a Mesozoic sedimentary cover at Mwene-Ditu and Kisenge; B. Mio-Pliocene, with most of the Mesozoic cover and overlying Paleogene Kalahari sands removed by Mid- to Late Eocene regressive erosion (see also Fig. 12).

Fig. 12. Paleogeographic sketches for three selected time intervals, with different geodynamic contexts. A. Campanian, with indication of the possible extent of the 'African Erosion surface' (etchplain extent after Guillocheau et al. (2018), enlarged to include Campanian ages obtained for Léro and the Kalahari Manganese Fields); note that the exposed landmass mimics the large cratonic areas, as they were assembled from c. $600 \mathrm{Ma}$ onward: $\mathrm{WAC}=$ West African Craton; CTBC $=$ Congo-Tanzania-Bangweulu Craton; KC $=$ Kalahari 
Craton (see text for further discussion). Blue stars are localities for which Campanian ages have been obtained. B. Mid- to late Eocene, marked by the rise of the East African Plateau. C. Oligo-Miocene, with opening of the East African Rift System (EARS). All sketches are based on ages obtained by the present study and on previously published data (Burke \& Gunnell, 2008; Anka et al., 2010; Theveniaut, 2012; Linol et al., 2015; Guillocheau et al., 2018; Vafeas et al., 2018b, Venancio da Silva et al., 2019). Red rectangle on the 3 figures study area.

Fig. 13. Validated ages and frequency diagrams of apparent ages (Kasekelesa (blue), Mwene-

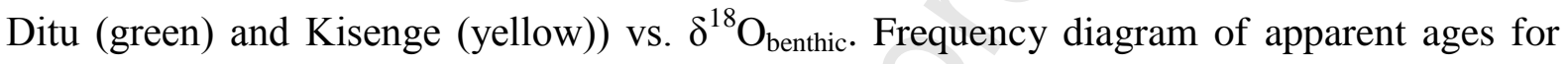
Tambao (Burkina Faso) in grey. See text for explanations. The colour codes of are those of the International Chronostratigraphic Chart. Reassessed $\delta^{18} \mathrm{O}$ curve of Friedrich et al. (2012), after Zachos et al. (2001 and 2008) and Cramer et al. (2009) which refers to chronostratigraphic chart of Gradstein et al. (2004). More recent and accurate chronostratigraphic chart established by Gradstein et al. (2012), matches from Oligocene to present with previous one (Gradstein et al., 2004), but differs sizeably for Upper Cretaceous (Campanian) and Paleocene. Reappraisals for these two stages, according to the chronostratigraphic of Gradstein et al. (2012) are shown as inserts. Recorded ${ }^{40} \mathrm{Ar} /{ }^{39} \mathrm{Ar}$ "events" are plotted on shifted $\delta^{18} \mathrm{O}$ curve segments. A readjustment was also processed for the Early Late Paleocene Event (ELPE) set at c. 58.4 Ma by Bralower et al. (2002) according to $\delta^{18} \mathrm{O}$ curve of Zachos et al. (1993) which refers to time scales by Berggren et al. (1985) and Cande \& Kent (1992) (Fig. 13). According to the chronostratigraphic chart of Gradstein et al. (2012), ELPE event would be as old as c. 59.5 Ma. 
Ms. Ref. No.: GR-D-19-00204

Title: Supergene manganese ore records 75 Myr-long Campanian to Pleistocene geodynamic evolution and weathering history of the Central African Great Lakes Region - tectonics drives, climate helps

Gondwana Research

\section{Credit author statement}

Thierry De Putter has written the paper, he has contributed the regional geology frame, ensured the integration of $40 \mathrm{Ar} / 39 \mathrm{Ar}$ ages as supports to the main line of reasoning of the paper, and discussed the data presented in the paper.

Gilles Ruffet has co-written the paper and has obtained the 40Ar/39Ar ages which are the backbone of the paper. He also contributed the anchoring of measured ages and 180 record, and detailed correlations with other sites in Africa he has worked on (Tambao, Burkina Faso). 


\section{Declaration of interests}

$\bigotimes$ The authors declare that they have no known competing financial interests or personal relationships that could have appeared to influence the work reported in this paper.

$\square$ The authors declare the following financial interests/personal relationships which may be considered as potential competing interests: 


\section{Research highlights}

Cryptomelane (supergene $\mathrm{Mn}$ ore) from south-eastern D.R. Congo was dated with the ${ }^{40} \mathrm{Ar} /{ }^{39} \mathrm{Ar}$ method in step-heating using a $\mathrm{CO}_{2}$ laser probe; ages are within a range of about $80 \mathrm{Myr}$ to $2 \mathrm{Myr}$.

A Campanian age (c. 76.4 Ma) obtained in this study is the oldest ${ }^{40} \mathrm{Ar} /{ }^{39} \mathrm{Ar}$ age that has presently been recorded for supergene $\mathrm{Mn}$ ores from Africa.

This Campanian age supports the formation of oxidized ore along a Upper Cretaceous or older erosion surface, which could be part of the "African Erosion Surface".

Tectonics is the $1^{\text {st }}$-order control for secondary ore formation in Central Africa, over the last $80 \mathrm{Myr}$. Climate is a $2^{\text {nd }}$-order control, as sufficient water supply is needed for supergene enrichment. 


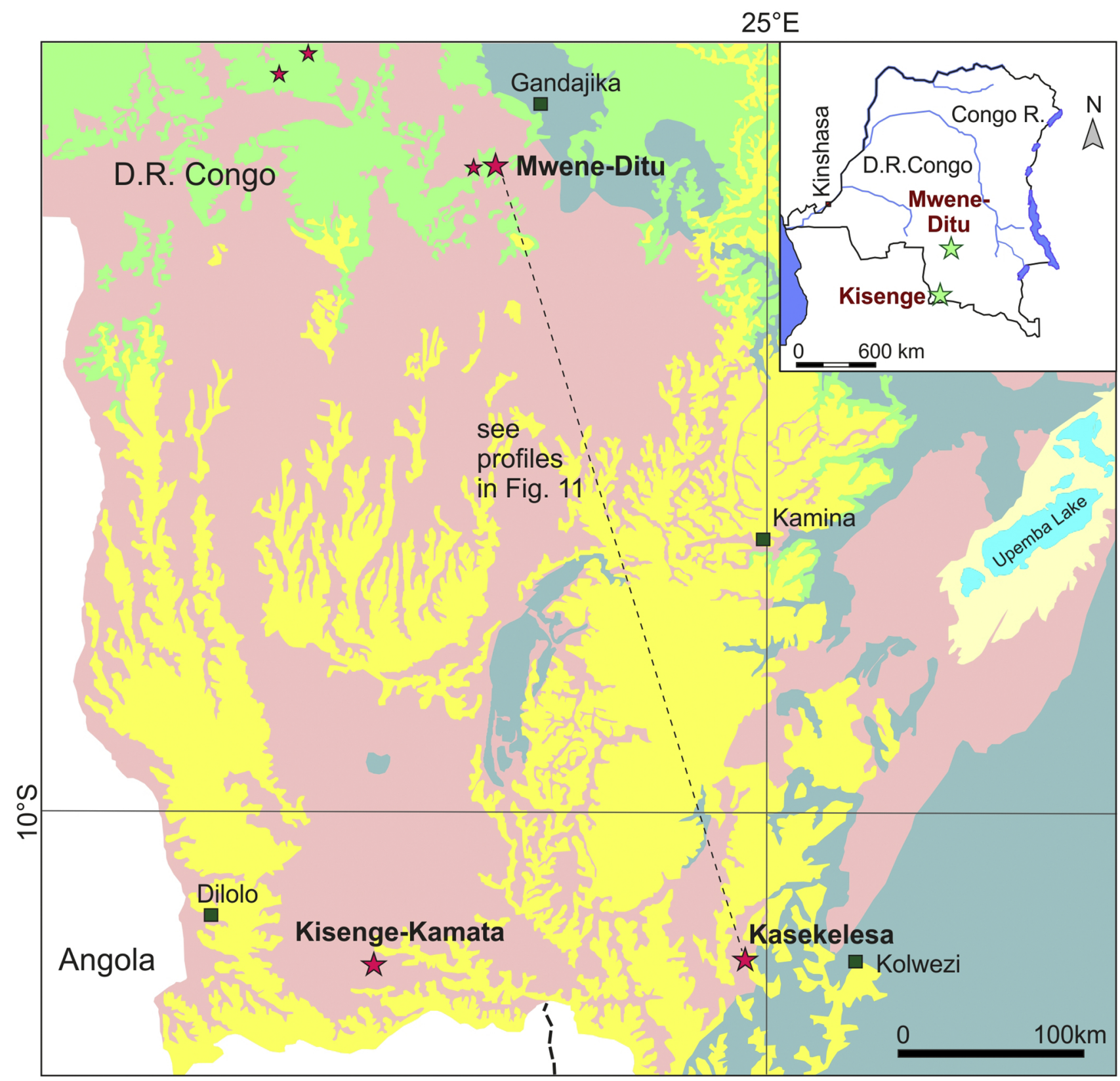

basement (Archean to Mesoproterozoic)

Neoproterozoic + Paleozoic

Mesozoic (mostly Cretaceous)

- Town

$\square$ Cenozoic (Kalahari Sands)

$\neg$ Holocene

$\star$ Manganese showing/deposit 

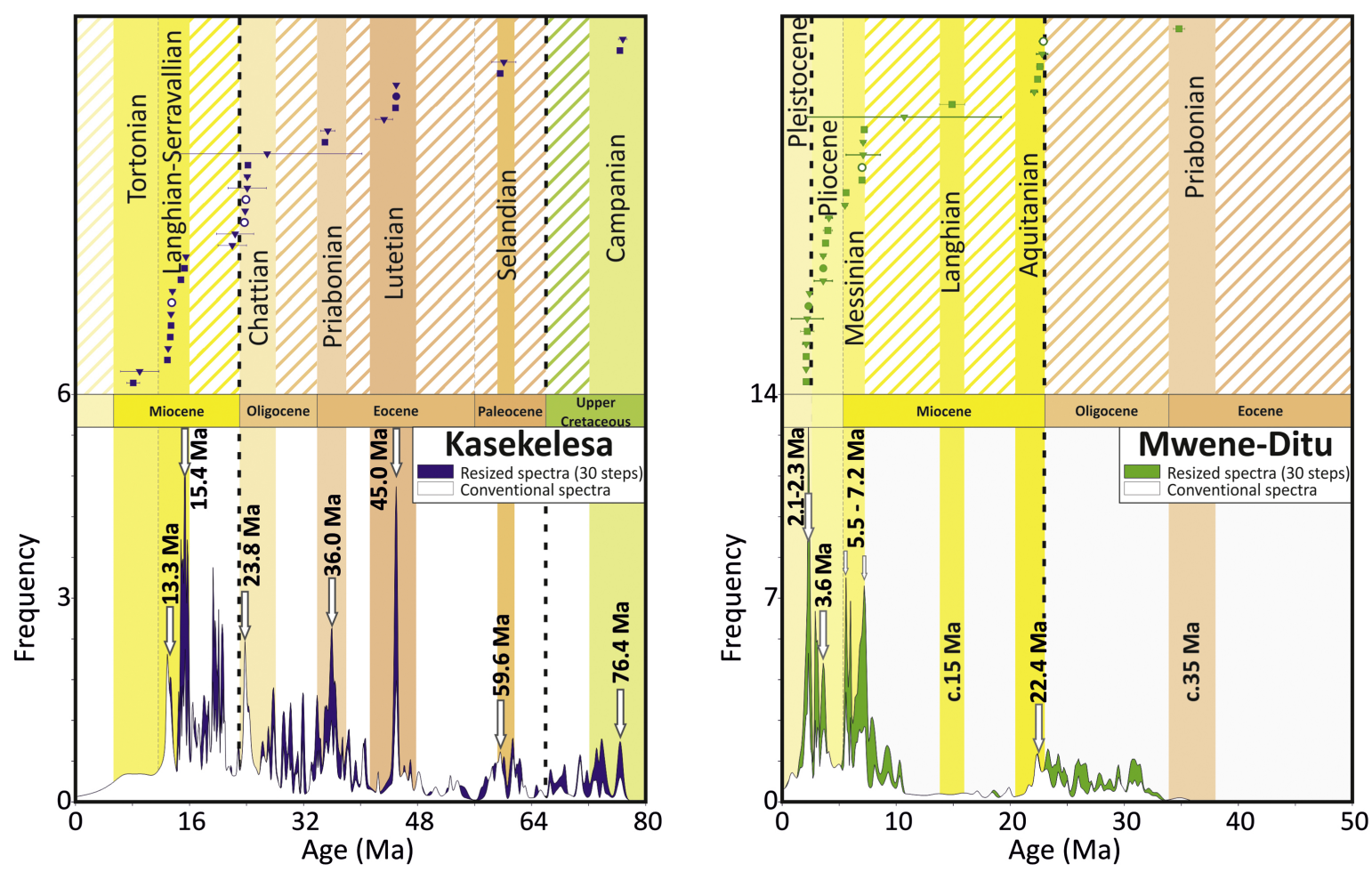

Figure 2 


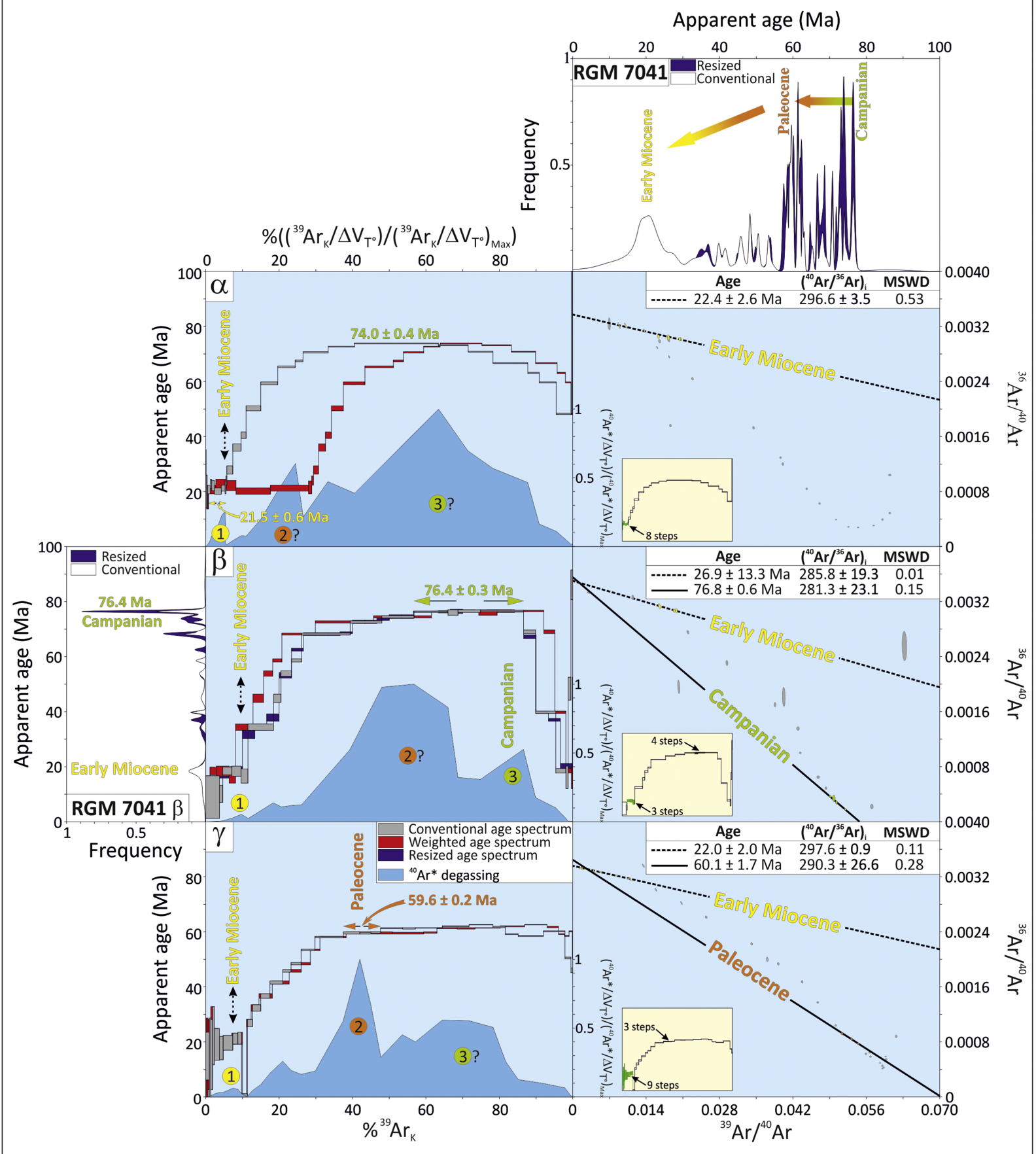




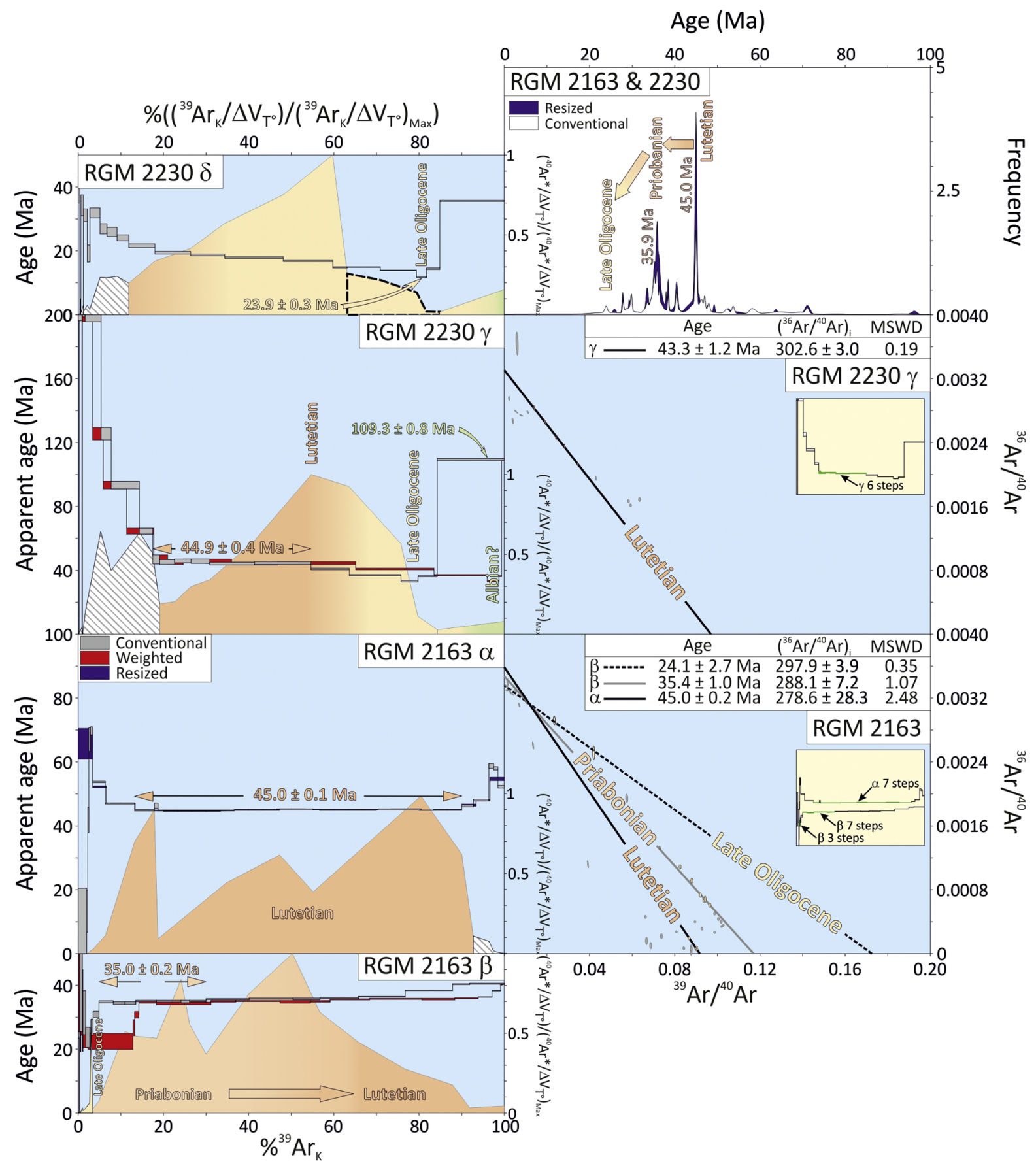




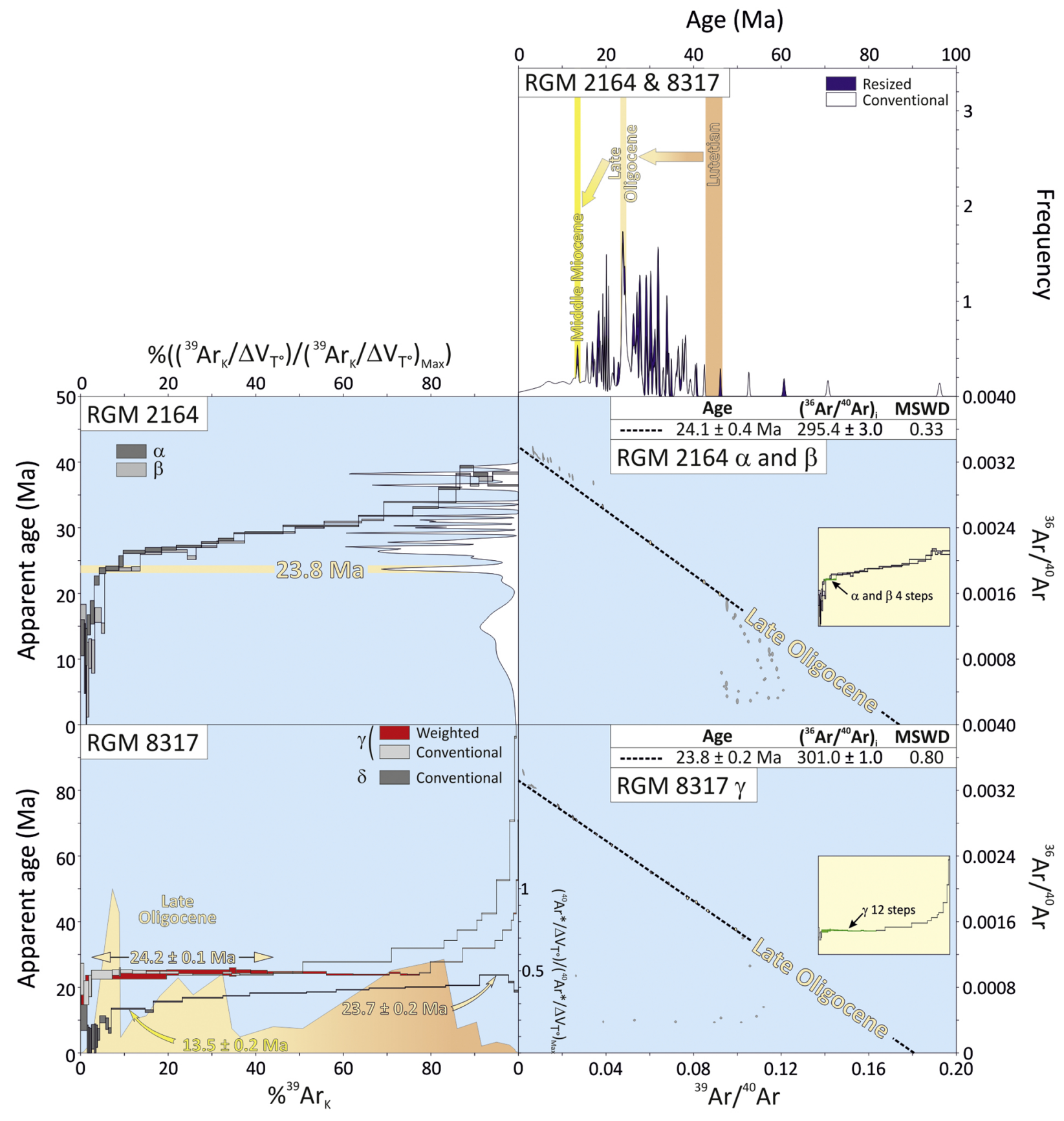




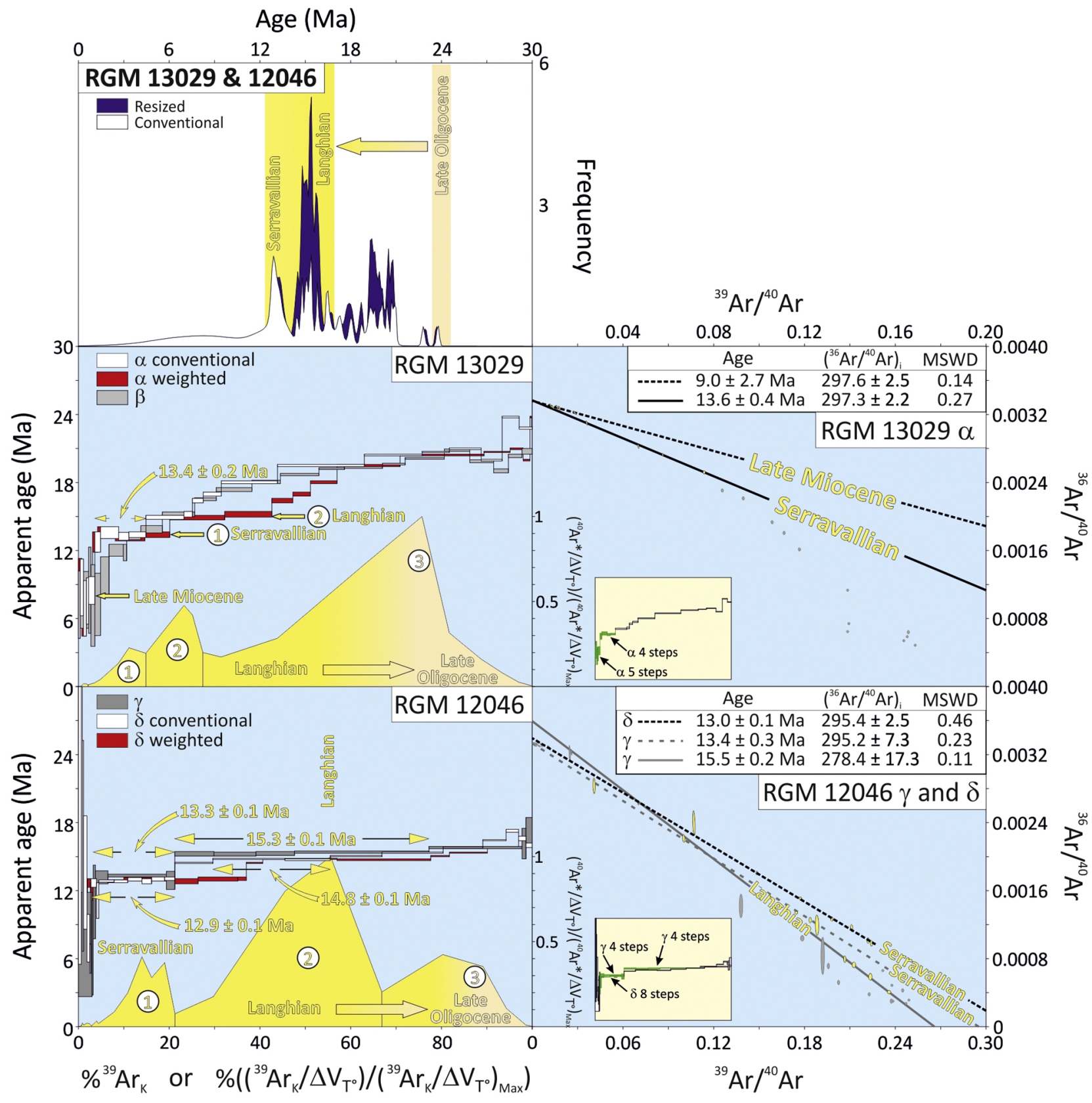


Age (Ma)

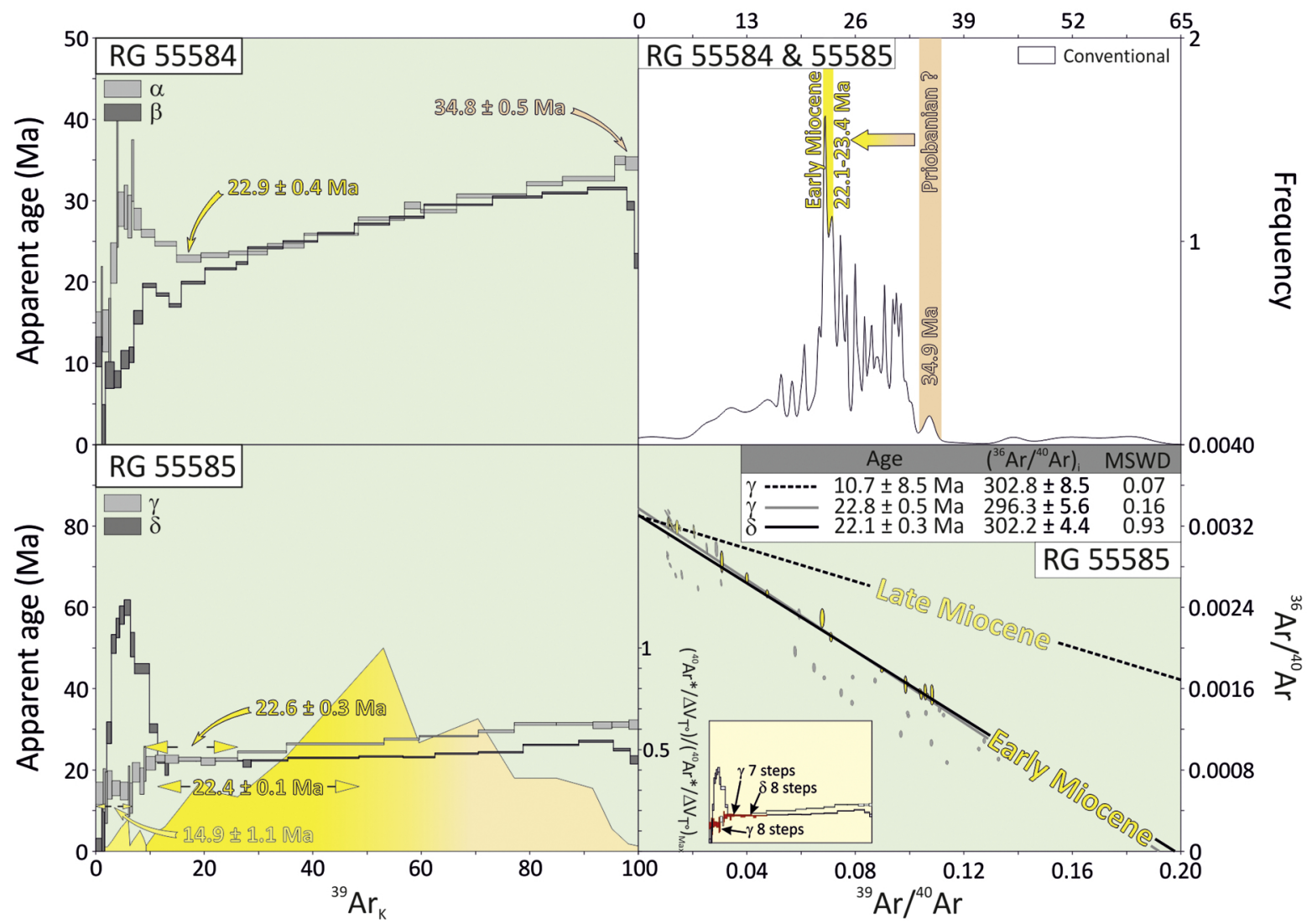

Figure 7 


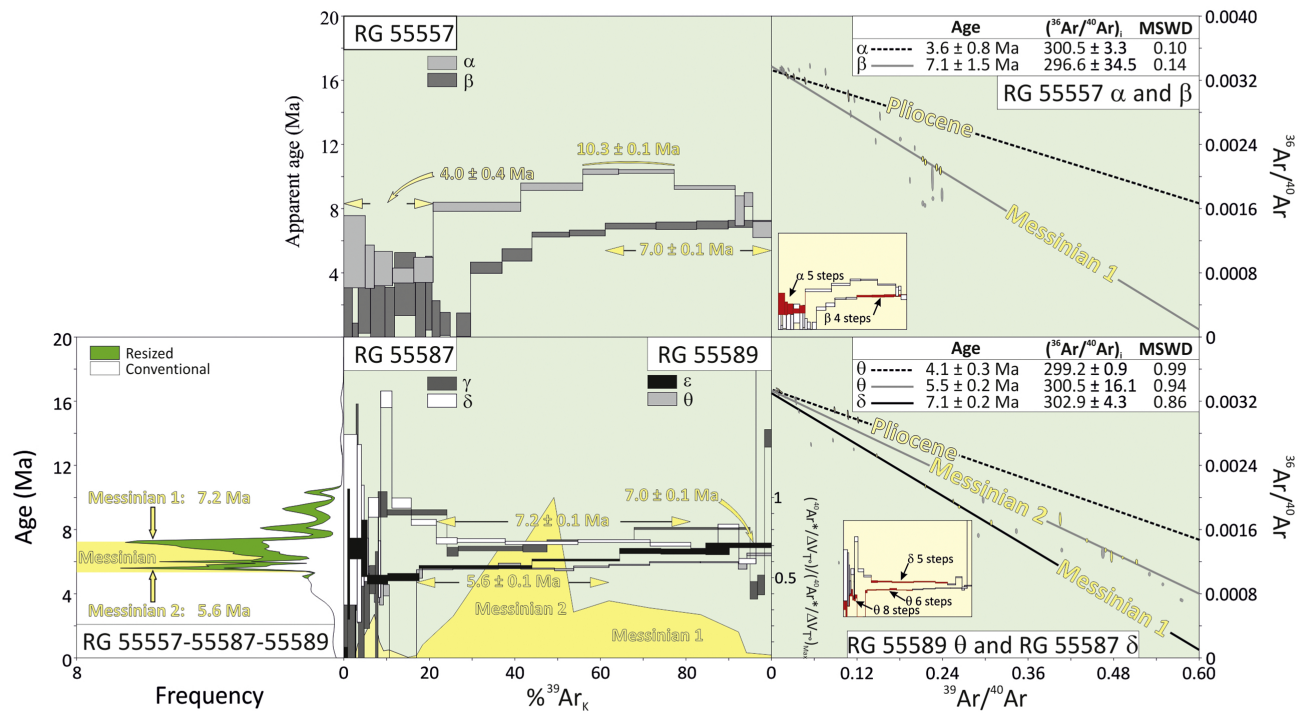

Figure 8 


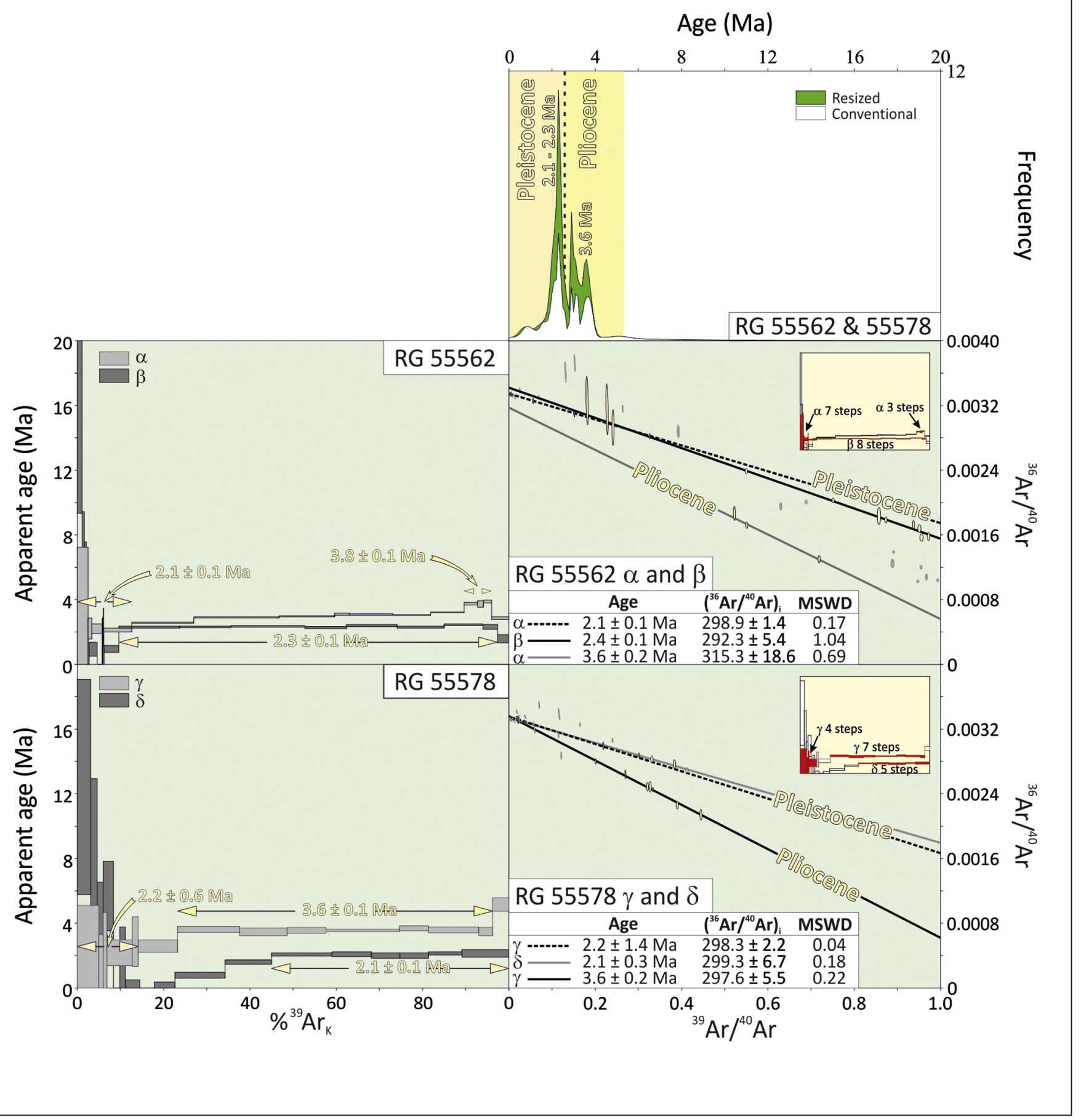

Figure 9 


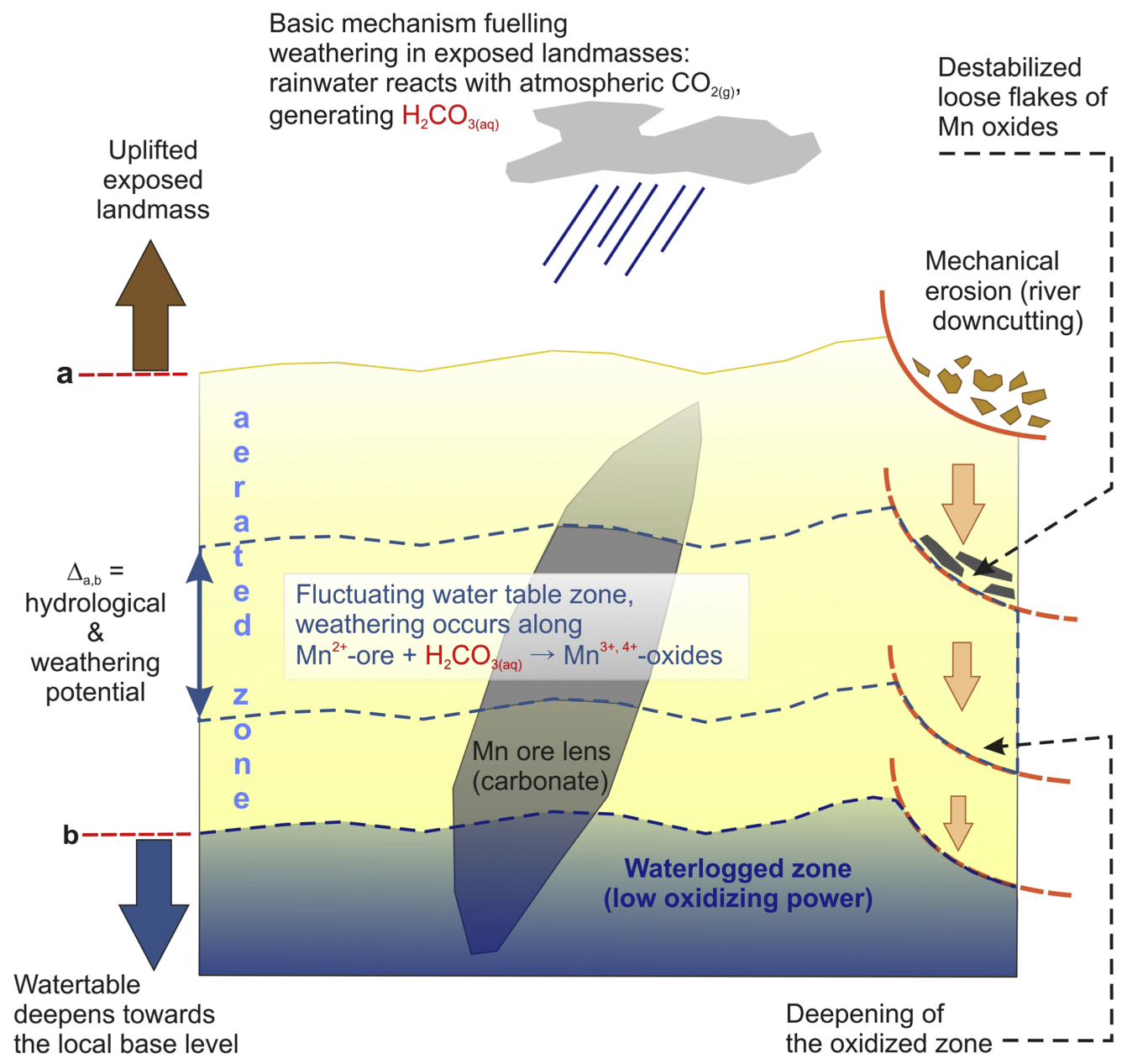




\section{A. Pre-Paleogene setting}

Deepening Congo Basin

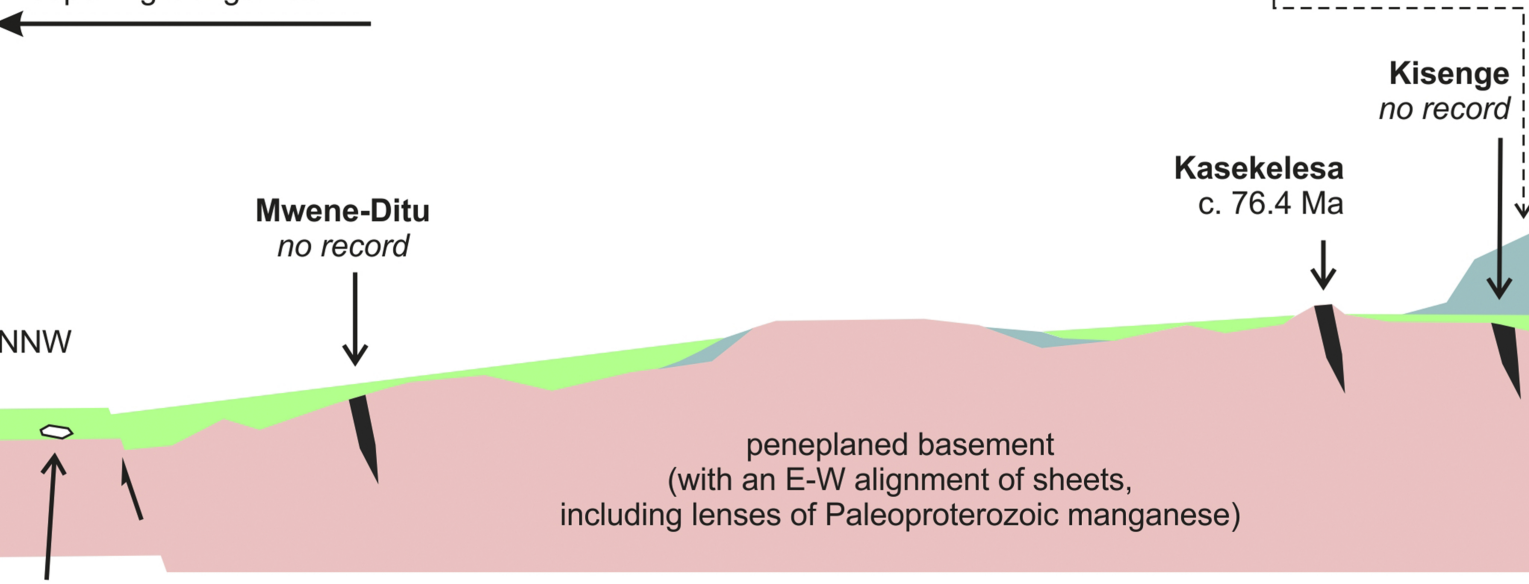

Kabinda zircons

dated 79-120 Ma

\section{B. Mio-pliocene setting}

Deepening Congo Basin

Mwene-Ditu

C. 35 - 22.4 - $15 \mathrm{Ma}$

\& younger than $7.2 \mathrm{Ma}$
Late Oligocene

or early Miocene

erosion surface

Kisenge

$>19.2$ - c. 15.7 - 14.2 -

$13.6-10.5-3.6 \& 2.6 \mathrm{Ma}$

Kasekelesa

c. 59.6 - 45 - 35 -

$23.8-15.4 \& 13.3 \mathrm{Ma}$

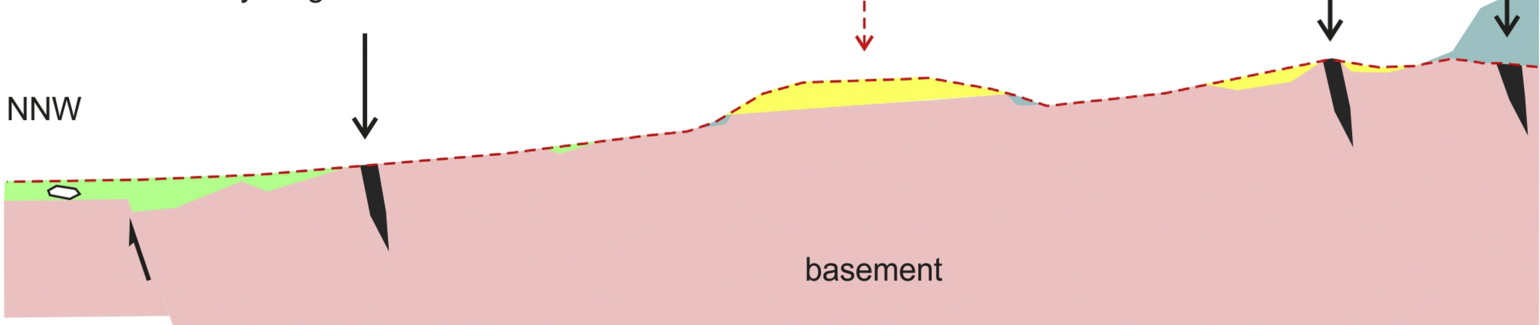

1400

1200

1000

800

600

$\mathrm{m}$

a.s.l.

basement (Archean to Mesoproterozoic)

Neoproterozoic + Paleozoic
Mesozoic (mostly Cretaceous)

Cenozoic (Kalahari Sands) 


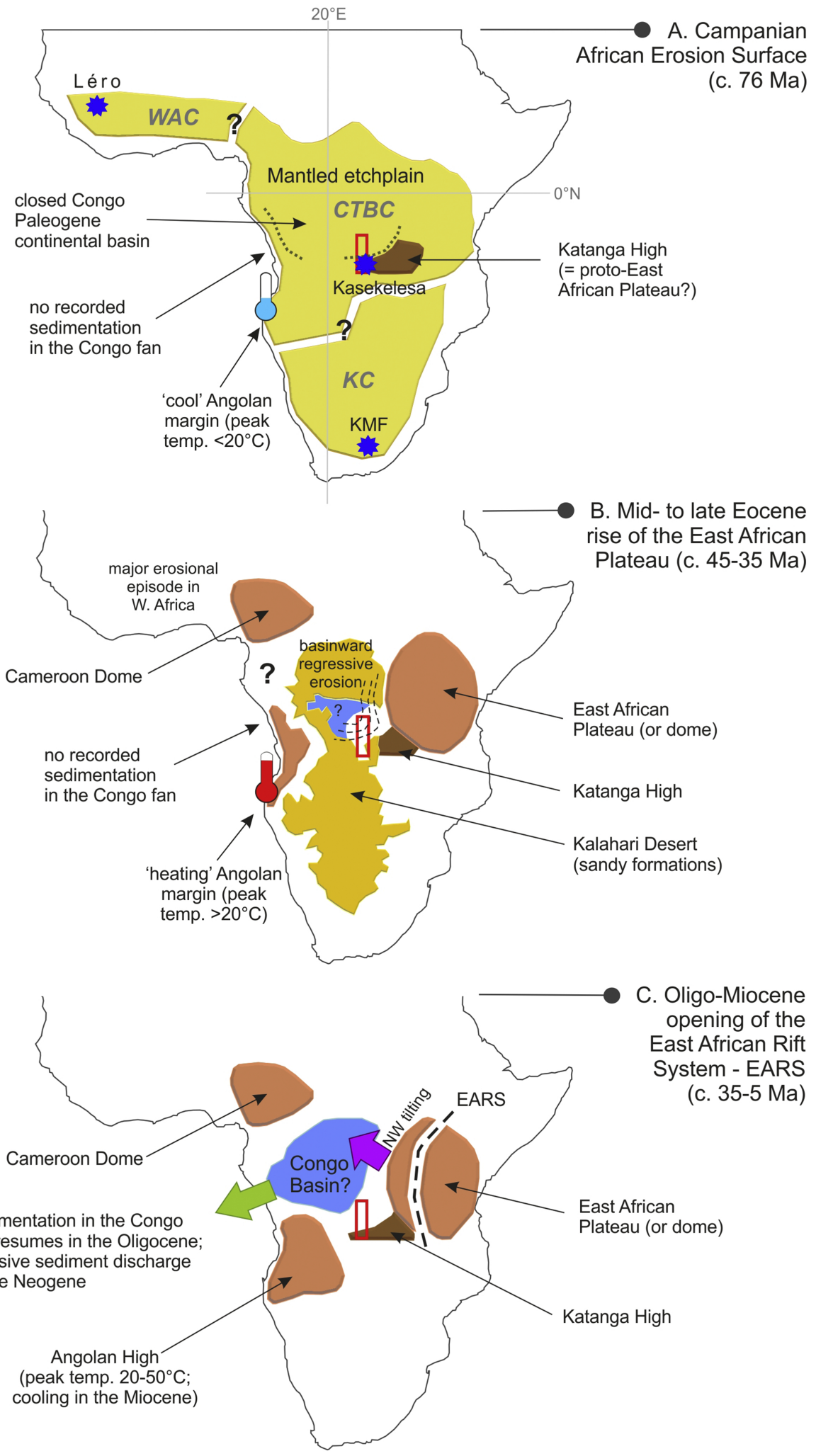




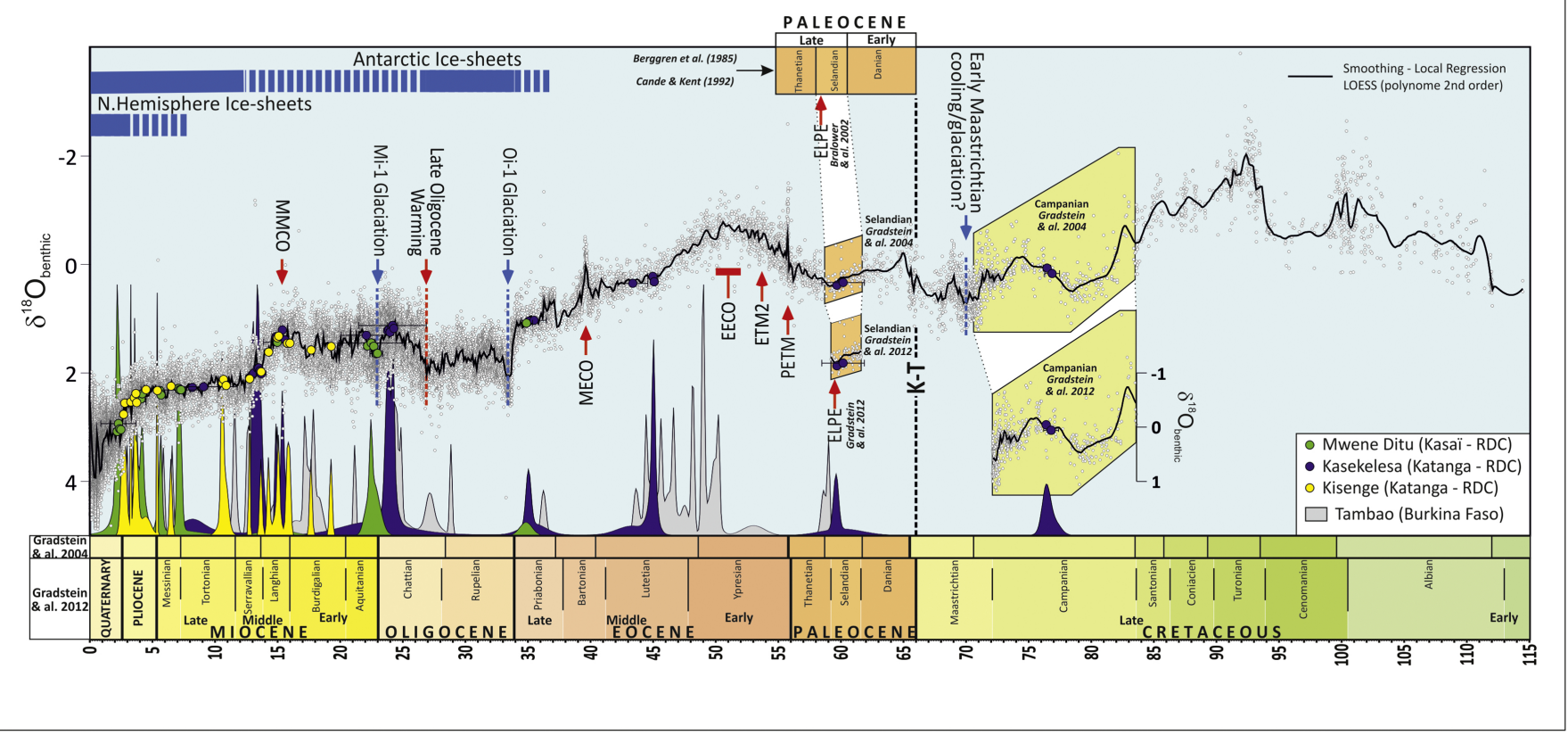

